\title{
RULES AND INFORMATION: AN INTEGRAL CRITICISM OF LEGISLATION
}

\author{
ESTEBAN PÉREZ MEDINA*
}

Fecha de recepción: 13 de mayo de 2016

Fecha de aceptación: 3 de octubre de 2016

Resumen: El objetivo de este trabajo es producir una crítica fundamental de la legislación. Sin embargo, para hacerlo, primero tenemos que comprender la naturaleza de las normas consuetudinarias. Para esta tarea, consideramos que es relevante el desarrollo de una teoría de reglas basada en la praxeología. Este trabajo estudia cómo el hombre genera reclamaciones sobre ciertos bienes económicos, cómo ellas pueden conducir a un conflicto y las complejas interacciones que se producen como consecuencia de ello. Llegaremos a la conclusión de que las reglas que se producen en una sociedad libre y como resultado de dichas interacciones, condensan información relevante que ayuda a la coordinación humana, propiciando una mejor resolución y evitación de conflictos futuros. Las reglas indican al hombre en qué expectativas puede confiar. A partir de esta teoría, vamos a explicar cómo la intervención en este proceso espontáneo a través de la legislación produce consecuencias críticas que sólo podemos entender después de reconocer el proceso de formación de reglas.

Palabras clave: praxeología, derecho, ley consuetudinaria, reglas, expectativas, orden espontáneo, función empresarial, legislación.

Clasificación JEL: KO.

Abstract: The goal of this paper is to produce a fundamental criticism of the legislation. However, to do so, we first need to understand the nature of customary rules. For this task, we find it relevant to develop a rule theory founded on

\footnotetext{
* Master en Economía de la Escuela Austríaca, Universidad Rey Juan Carlos. Abogado en libre ejercicio.
} 
praxeology. This work studies how man produces claims over certain economic goods, how those claims can lead to conflict and the complex interactions that take place as a consequence of this. We will conclude that the rules produced in a free society as a result of said interactions condense relevant information that aids human coordination, propitiating a better resolution of future conflicts as well as their avoidance. Rules tell man what expectations he can rely on. Parting from this theory, we will explain how intervention on this spontaneous process by way of legislation produces critical consequences which we can only understand after acknowledging the process of rule formation.

Keywords: praxeology, law, customary law, rules, expectations, spontaneous order, entrepreneurship, legislation.

JEL codes: KO.

\section{I \\ INTRODUCTION}

To produce a withering criticism of the legislation we first need to establish what nature and spontaneous origin of customary law are. ${ }^{1}$ Only by understanding the organic process of customary law emergence can we grasp the consequences of artificial interference with it. Over the years many criticisms to legislation have been produced, two of which stand out: Bruno Leoni's Freedom and the Law and Friedrich von Hayek's Law, Legislation, and Liberty. However, persuasive as they are, it is in our opinion that they fail to give the coup de grace. The reason is they do not focus enough on developing a general theory of law and focus too much on pointing particular disadvantages of legislation. ${ }^{2}$

It is in our believe that only by developing a general theory of customary law can we understand the deficiencies of constructed

\footnotetext{
${ }^{1}$ We generally use the terms «customary law» and «law» indistinctly to refer to law as a process of spontaneous human interaction. We use the term «legislation» to refer to «made law.» (See Fuller 1981, 212).

${ }^{2}$ Hayek's development, though seminal, is not a full-fledged criticism to legislation, but partial. We will develop on the reasons why we hold this view in the final section of this paper.
} 
legislation. The path to attaining such a theory was already hinted by Leoni when we posed the actual nature of the legal process:

[T] he whole process [of law formation] can be described as a sort of vast, continuous, and chiefly spontaneous collaboration between the judges and the judged in order to discover what the people's will is in a series of definite instances - a collaboration that in many respects may be compared to that existing among all the participants in a free market. (Leoni 1991, 22).

The analogy he makes between law and market is a powerful one. It allows us to inquire into the nature of the legal process using the already successful methods of economic understanding. It is our suggestion that, through these methods, we might start to draft a general theory of law that accounts for the shortcomings of legislation.

However, the particular method of economic science we are interested in is the one championed by the Austrian school of economics. ${ }^{3}$ One of this school's particularities is that, since its inception, it has been perceptive of the similarities among the economic and legal processes. Its founder, Carl Menger, noticed that certain social phenomena of the utmost relevance in both spheres appeared not as a product of design, but «organically,» (see 2009, 147) and were the consequence of individuals seeking their particular interests, (See 2009, 157) which, nevertheless, produced social benefits. He called these phenomena institutions. His research focused on one of these institutions: Money. From simple elements of human behavior and interactions, he arrived at a theory of the organic generation of general means of exchange. (See 2009, 149-50). ${ }^{4}$

\footnotetext{
${ }^{3}$ Different approaches to legal phenomena from the economic point of view abound in the academy. (See Cooter and Ulen 2011; Posner 2014) However, only the Austrian school studies economy assigning the preeminent role to a general theory of action and choice. As we will develop in this paper, we find this particular approach most accurate to produce a true assessment of how the legal phenomenon appears in society.

${ }^{4}$ Menger describes the early stages of exchange as those in which each party would only give up their goods in exchange for goods with a higher use value to them. However, this early stage faces a problem of «double coincidence,» for exchanges will only be made when both parties value the good owned by the other higher than theirs.
} 
He also noticed the existence of many other institutions, like language and rules of law, and proposed that we trace their origins to particular human actions and interactions. (See 2009, 147).

The theoretical understanding of them [institutions], the theoretical understanding of their nature and their movement can [...] be attained by reducing them to their elements, to the individual factors of their causation, and by investigating the laws by which the complicated phenomena of the human economy under discussion here are built up from these elements. (Menger 2009, 158-59).

The essential feature of the Austrian school is that it frames economy in the study a more general science, which Ludwig von Mises called praxeology, ${ }^{5}$ the science of human action. (See 1998, 1129) Praxeology is useful to reduce complex phenomena to the particular human attitudes that produce it. It is our believe that any study of law, as of any other social phenomenon, needs to start

But «[a]s each economizing individual becomes increasingly more aware of his economic interest, he is led by this interest, without any agreement, without legislative compulsion, and even without regard to the public interest, to give his commodities in exchange for other, more saleable, commodities, even if he does not need them for any immediate consumption purpose.» $(2011,260)$ Only a small number of individuals will recognize and profit from this information. However, eventually, and due to the self-interest of men seeking profits, it will become available to a great portion of the population which will prefer a particular commodity as a general means of exchange, solving the problems of the early stages. (See 2011, 157-61) The author described this as a spontaneous process, alien of human design, by focusing on the particular human interactions that produce it. These interactions are: the entrepreneurial awareness that permits men to find a profit opportunity in non-direct exchanges and profit-seeking that brings other men, once the information is available, to imitate this behavior. We can summarize them as a two-stage process: at first, there is intellectual production by a pioneering elite followed by a stage of imitation and adoption by the rest of society. (See Lachmann 1971, 68).

${ }^{5}$ Praxeology is the general theory of human action, which takes into account a general theory of choice and preference as the fundamental that determines all human decisions. As such, praxeology is a general science to which economics, and arguably law, is only a part. (See von Mises 1998, 3).

The method of praxeology is methodological apriorism, it parts from certain a priori truths of the human logical structure. (See von Mises 1998, 35-36) As such, it is purely conceptual and deductive, its implications logically derived from the premises. Praxeology differs from natural sciences in that is doesn't rely on empiric data to produce knowledge of reality. (See 1998, 38-40). 
with the general theory of human action. With the tenets of praxeology as a background we seek to produce a praxeological rule theory - a general theory of how rules of law, ${ }^{6}$ particularly substantial and remedy rules, ${ }^{7}$ emerge in a free society- which is to be just one part of the general theory of law. Once we bring about this theory, we may evaluate its consequences in real world legal systems, and analyze particular instances of the law from a praxeological perspective. What this exercise will show is that law, because it is a product of free human action, condenses information on individual preferences and adapts to them in ways in which legislation, or any other artificial command, cannot.

To sum it up, the purpose of this work is to produce an integral criticism of the legislation. Put in other words, to produce a fundamental normative justification of customary law. To do so, we will explain the emergence of law as a product of human interaction using the method of economic science, particularly the Austrian method. We will start with the basic premises of human action and deductively construct a theory of rules. Once we achieve it, we will analyze the effects of legislation from this viewpoint. Only then we will be able to produce a complete criticism of it.

For this purpose, we will divide the paper into seven sections. In section II we will start from the basic tenets of human action. We will explain how these principles can account for the appearance of conflicts among individuals. In section III we will focus on the implications and methods of solving human conflicts. We will expound which is the necessary institutional background to do so and the complex human interactions that take place while solving conflicts. The understanding of these interactions in subsection 2 are the core of our rule theory. In section IV we will inquire into the generation and function of rules. We will study the information they condense and how it aids human cooperation in a world of free legal forums. Section $\mathrm{V}$ is devoted to the study of legislation

\footnotetext{
${ }^{6}$ We use the term «rule» exclusively to refer to customary rules of law. Rules are the particular norms that form customary law.

7 We use the terms «substantial» and «remedy rules» to refer to rules directly governing human relationships and conducts and ascribing them consequences, different from procedural, constitutive and controller-selecting rules. (See Ellickson 1991, 132-36).
} 
as an alternative to rules, and the many consequences of picking one or the other. We will end this paper in section VI with some concluding remarks on the benefits this new perspective brings, as well as the many challenges it still faces ahead. An epilog studies some implications of a praxeological rule theory to legal theory, legal philosophy, the evolutionary theory of Institutions, and the theory of dynamic efficiency.

\section{II \\ HUMAN ACTION AND HUMAN CONFLICT}

\section{Human Action and Expectations}

Any praxeological study starts with man and his external manifestations, his actions ${ }^{8}$ :

Human action is purposeful behavior. Or we may say: Action is will put into operation and transformed into an agency, is aiming at ends and goals, is the ego's meaningful response to stimuli and to the conditions of its environment, is a person's conscious adjustment to the state of the universe that determines his life. (von Mises 1998, 11).

Men acting always seek to go from a less satisfactory state of affairs to a more satisfying one, (see von Mises 1998, 13) and they can do so because they can discover causal relations. (See von Mises 1998, 22) Men's purposeful behavior is necessarily rational. ${ }^{9}$ It is also necessarily autonomous; only humans can act, and they are the «prime-movers» of their actions. (See Rothbard 2004, 2-3; von Mises 1998, 17).

In their environment, men find two types of elements, those they can control and those they cannot, the former being means to

${ }^{8}$ The principles of human action developed by Mises are here superficially explained. We did not devote a throughout analysis of them but take them as a given from which we start our development of the rule theory.

${ }^{9}$ By «rational» we mean it is goal-oriented, seeking what is perceived as suitable means to attain an end. (See von Mises 1998, 18-19). 
attain their ends. (See Rothbard 2004, 3-4) Means are necessarily scarce, for otherwise all human ends would be abundantly attainable. ${ }^{10}$ We call these means economic goods and men value them according to the ends they think they can satisfy. The human body, labor, land and time are also economic goods. (See Rothbard 2004, 310-14).

Time is a resource always present in human action. It entails uncertainty, for men never fully know what the future conduct of other men will be, though they can probabilistically speculate on it. In the realm of human action, we have case probability rather than class probability. That is, not a mathematical probability in the aggregates, but particular case probability based on influencing factors which affect only those special cases. ${ }^{11}$ The process of speculating on future conditions is what we call an act of entrepreneurship.

${ }^{10}$ Scarcity means that no two simultaneous or contradictory actions may be taken regarding the same object, they are «limited with respect to the ends that they could possibly serve.» (Rothbard 2004, 5) Scarcity forces agents to economize their goods, signing them to their most desired ends. As such, scarcity is always subjective: Goods are scarce only in relation to human action and never scarce in themselves.

«Perhaps the nature of subjective scarcity may be illustrated more simply. Imagine a world in which everyone's preferences for resource use were naturally coordinated in the sense that no one ever subjectively desired to put a resource to more than one use; that no one ever subjectively desired to use my particular resource at the same time as any other person; that, though individual preferences concerning resource use differed, every preferred use could be acted upon without physically impeding in any way the preferred actions of others; in sum, a world in which all subjectively desired uses were compossible with each other. In such a world, while all resources could be as physically scarce as they are in our world, we would face no subjective scarcity.» (See Barnett 2014, 39).

${ }_{11}$ «Class probability means: We know or assume to know, with regard to the problem concerned, everything about the behavior of a whole class of events or phenomena; but about the actual singular events or phenomena we know nothing but that they are elements of this class.» (von Mises 1998, 107) This probability is particular to the natural sciences; it is mathematizable and empirically attainable.

«Case probability means: We know, with regard to a particular event, some of the factors which determine its outcome; but there are other determining factors about which we know nothing.»

«Case probability has nothing in common with class probability but the incompleteness of our knowledge. In every other regard the two are entirely different.» (von Mises 1998, 11) This probability is characteristic of the sciences of human action. It studies historical and unrepeatable events by valuing the influencing factors through speculation. 
(See Rothbard 2004, 64) Based on those acts, men elaborates plans and behave accordingly.

With this in mind, we can develop on some additional particularities that are at the origin of the legal phenomenon. We know «[h] uman actors value means [economic goods] strictly in accordance with their valuation of the ends that they believe the means can serve.» (Rothbard 2004, 20) Through entrepreneurship, that is, by speculating on the future through case probability, they tell how probable it is that they will be able to enjoy these services from particular economic goods without the interference of third parties. ${ }^{12}$ They can weigh how likely it is that third parties will respect and uphold this enjoyment. We call this kind of speculation an expectation..$^{13}$ When a man, let's say, Paul, buys a mule from Papinian, he comes to expect as very likely that he will be able to enjoy the services the mule can render him. For instance, if he wants the mule to carry grain he thinks is probable he will be able to enjoy this service.

The duration of serviceableness of an economic good also affects man's expectations. "[T] $]$ he expected durative power of the consumers' good to serve his end will enter into the actor's plans.» (Rothbard 2004, 16) He will not only speculate on how probable it is for him to enjoy a certain service but also over what period. Paul expects as likely he will be able to use his mule to carry his grain today, but he also expects it tomorrow and the day after, until for natural reasons the mule is unable to render that service.

However, case probability cannot be mathematically or cardinally measured, only ordinarily compared. Because of this, man always tries to speculate on the probability he has of enjoying the services of an economic good without interference comparing it to

${ }^{12}$ We need to stress the fact that we use the term «entrepreneurship» in its most abstract and general sense, following the Austrian tradition. By it we mean the ability of men to speculate on future conditions and act on them in a way they deem beneficial.

${ }^{13}$ We use the term «expectation» exclusively in this sense and not in any colloquial sense. Expectations are entrepreneurial acts by which an individual speculates on the likelihood that other individuals will approve his use and enjoyment of particular economic goods. They inform external manifestations, be them action or inaction regarding the particular good. 
what he values as the probabilities other particular individuals have. ${ }^{14}$ If in his expectations man values the probability of sanction $^{15}$ of his enjoyment of the services of an economic good as higher than that of some other party, we can say he has a claim on said services over that party. (See Leoni 1991, 197) ${ }^{16}$ After Paul buys his mule, and according to his expectations over it, we can say he has a claim on it over the former owner, Papinian. Claims are always about somebody else, and when stated plainly, like in «Paul has a claim on the mule,» what they mean is he has a claim over everybody else (erga omnes).

However, expectations, like any entrepreneurial act, are subjected to entrepreneurial error. Man can inaccurately attribute social value to certain circumstances, and therefore be wrong on his conclusions about the probabilities certain enjoyments have of being respected. When such wrong speculations are the root of claims, we say they are not legitimate claims. ${ }^{17}$ Accurate probability speculations are the core of legitimate claims.

As we will see, claims are the core human manifestations that originate legal rules, just as Leoni proposed:

${ }^{14}$ At this point, we part from Leoni's concept of probability and embrace that of Mises, as stated above. Leoni thinks all probability has to be assessed by case repetition, and when such is hard to attain - as in the case of human conduct-, we have to represent it mentally based on the known facts we dispose of. (See 2013, 78) Mises' case probability is not based on repetition but on influencing factors that may provoke a particular outcome and is, therefore, more suitable and less arbitrary to the study of human conduct. (see 1998, 11-12).

${ }^{15}$ Throughout this paper, we use the term «sanction» in its non-legal definition: «authoritative permission or approval, as for an action.»

${ }^{16}$ Leoni acknowledges that individuals base their claims on what he calls forecasts, and we have called expectations. (See 2013, 70) He also states that forecasts are always related to human behavior and not natural phenomena. (see 2013, 72) We imply this idea when we point that expectations are acts of entrepreneurship.

Claims are always causal propositions which state that: Given that the individual has certain expectations (in which he considers his actions have high probability of being sanctioned), he demands that his enjoyment of the service of certain economic goods be respected accordingly. They are based solely on expectations and not on any other material or metaphysical basis.

17 «In this respect, we can distinguish claims that we consider unsubstantiated from claims defined as illegitimate, not because they are unsubstantiated but because they are against common expectations in a particular ambit.» $(2013,82)$ (Translation by the author). 
It is my suggestion that legal philosophers as well should trace back legal norms as social phenomena to some individual acts or attitudes. These acts reflect themselves in some way in the norms under a legal system. [...] I suggest also that those individual acts and attitudes be called demands or claims. $(1991,192)$.

\section{Human Conflict and Expectations}

Frequently two different individuals may have incompatible expectations, and as long as these expectations are opposed, there is discoordination among them. This incompatibility is always the product of an entrepreneurial error in generating expectations, be it from one or both parties. According to Paul's expectations, he may have a claim on his mules over everybody else. However, unknown to him is the fact that Ulpian, to whom Papinian was indebted, estimates that because of his credit, now he has a claim on the same mule over everybody else. ${ }^{18}$ In this case, both have clashing claims, and we can conclude that either they are both somewhat illegitimate, or at least one of them is.

If two autonomous ${ }^{19}$ individuals have incompatible expectations it is inevitable that one of them experiences costs. ${ }^{20}$ This is

${ }^{18}$ Let's assume, for the sake of the argument, that Ulpian just believes this, but has no contractual support. The mule is not collateral to Papinian's debt with him.

${ }^{19}$ As we mentioned, human action is necessarily autonomous and only autonomous men can act according to their expectations. In strict command-and-obedience relationships man cannot act, but only follow orders. In this case, only the commander can properly be said to act.

Material conflict necessarily involves autonomous agents. As Hayek said: «Since for a case to come before a judge a dispute must have arisen, and since judges are not normally concerned with relations of command and obedience, only such actions of individuals as affect other persons, or, as they are traditionally described, actions towards other persons (operationes quae sunt ad alterum) will give rise to the formulation of legal rules.» (1978a, 101).

Van Dun develops extensively on autonomy in a legal order. (See 2003)

${ }^{20}$ Costs are «the value attached to the satisfaction which one must forego in order to attain the end aimed at.» (von Mises 1998, 97) Or in the case at hand, costs are satisfaction foregone as a consequence of the attainment of another party's end.

Cost are always subjective, for they are relative to the evaluation of men. They are also a logical consequence of the fact of scarcity mentioned above, for no good can serve simultaneously to two different and contradictory ends (or satisfactions). 
evidenced by the actions derived from conflicting claims. For instance, if Ulpian, according to his expectations, decides to capture the mule, Paul will experience costs - a lost mule-.${ }^{21}$ This interaction is what we call material conflict.

The main characteristic of material conflict is that it is always a conflict on the services of an economic asset and necessarily generates costs to one party. It, therefore, always entails incompatible expectations over those same services. There is, arguably, a different kind of conflict, spiritual conflict. These are not conflicts on economic goods and therefore do not generate costs. It is not a conflict over the means of human action but on its ends, and ends are not scarce. The spiritual conflict involves no relevant external manifestation from man and therefore is of no praxeological interest.

A claim frustrated due to material conflict tends to generate new expectations on the agent which, in turn, generates new claims. For instance, after Ulpian seizes the mule Paul can make various new claims as a response. He can consider he has been robbed - that he had a legitimate claim on the mule- and claim it back (or even seize it) from Ulpian, causing further conflict. Paul may also consider Ulpian has robbed him, but claim (or seize) not only the same mule but an additional one. In this case, there are inconsistent claims on both the same asset (original mule) and a new one (additional mule). ${ }^{22}$ Finally, Paul may think Ulpian robbed him but claim (or seize) not the mule but a monetary compensation instead. In this case, he generates a claim over a new economic good, but the expectations over the former become consistent (they both accept the mule is Ulpian's now) ${ }^{23}$ Finally, Paul can conclude that Ulpian's claims were legitimate and decide to

${ }^{21}$ In any case of conflict there is always an invaded party and an invader party. We define the invaded party as the party experiencing the costs once the conflict arises, which may be due either to the action or the omission of the invader.

${ }^{22}$ In this case, we arrive into what we call a case of complex conflict. There is not one conflict - a clash of claims over some particular services of a particular economic good- anymore, but two, for parties claim the services of two different goods, the original mule, and the new mule.

${ }^{23}$ In this case, the remaining conflict (over the monetary compensation) is different from the first conflict (over the mule) even though it was provoked by the latter. 
give up any claim..$^{24}$ Only in the latter case, both parties are going to have complementary expectations on all means.

Until both sides' expectations over the many relevant economic goods are complementary - until there is coordination among them-, the conflict remains. As mentioned, sometimes parties' expectations will become complementary casually (like in the last situation), but this is not usually the case. Parties with non-complementary expectations can, therefore, seek to solve these inconsistencies - resolve their conflict- or can hold to them - continuing it-. The first position seeks coordination while the latter can potentially generate a spiral of conflict.

If parties decide to continue in conflict, there are some costs they will have to take care of. ${ }^{25}$ First, as we have seen, every conflict generates costs. A spiral of conflict can potentially cause immense amounts of costs to both parties. Also, remaining in conflict generates considerable uncertainty. Each party knows the other has conflicting claims, but find it hard to assess which they are and how and when will the other act on them. They cannot anticipate the costs of the other's actions and make proper use of their resources to face them. Finally, social punishment is a traditional institution that maximizes the costs of conflict. One chief penalty is ostracism, which labels the reluctant individuals who fail to solve conflicts and expels them from social interaction. Aggressors not willing to solve their conflict will not only have to deal with the costs of economic goods and the costs of uncertainty, but also the expenses of a general refusal to deal in society. Given the nature of human society and its dependence on the division of labor, ostracism's costs are usually prohibitive to any individual. (See Benson

\footnotetext{
${ }^{24}$ Or, alternatively, voluntarily «give away» the mule to Ulpian to avoid future conflict.

${ }^{25}$ The possibility of parties never deciding to solve their conflict has been the fundamental argument with which political intervention in law is justified nowadays. Some hold that we need a last resource authority to force unwilling parties to settle their disputes. Otherwise, we will soon find ourselves in a «war of all against all.» (See Rand 1964b, 125-34).

The former was the main argument by John Locke and Thomas Hobbes: That free man would succumb to their passions and be unable to live by the law. An authority needed to be established to have a last say in particular conflicts. (See Hobbes 1994; Locke 1980).
} 
2011, 295-97; Leeson 2014, 15-56) ${ }^{26}$ These costs create strong incentives to reach a solution before conflict escalates. (See Sugden 2005, 61).

There are also costs in solving the conflict, which can be less or more attractive to the individuals when compared to the alternative. Additionally, there are many alternatives to address a conflict, which, in turn, may have different costs in different situations. The next chapter develops on what happens after parties decide to solve their conflict.

\section{III \\ SOLVING HUMAN CONFLICT}

\section{Institutional Considerations}

If both parties decide to solve their conflict, they will be able to avoid future conflicts and the costs they might cause. What they may not avoid are the costs already experienced by one party (or both). Paul and Ulpian may seek to solve their differences, but they cannot prevent the fact that Paul has already experienced the loss of a mule. The task of solving the conflict demands that they agree on who is to bear these costs, either the invader (Ulpian) or the invaded (Paul). ${ }^{27}$ Either Paul is forced to internalize the costs or Ulpian is obliged to restitute him.

The best way to solve this question is by reconciling their expectations over the economic asset in dispute. To do this, they need

\footnotetext{
${ }^{26}$ Ostracism is not a radical or far-fetched solution to the problem of non-abiding individuals. Ancient Romans practiced it under the figure of «capitis deminutio maxima», which was a legal penalty that withdrew legal personality, rights, and citizenship from the convict, forbidding him to deal with other Roman citizens. (See Iglesias 2010, 106) Banishment, another particular form of ostracism, has also been practiced in many societies throughout history.

${ }_{27}$ There are cases in which the spiral of conflict escalates before both parties decide to solve them. These are always cases of complex conflict, for there are always several unresolved conflicts latent in them. In these cases, both parties play both roles to some extent. In Paul's case, if he decided to seize the mule back before solving his conflicts with Ulpian, the latter would be the original invader, but Paul would also be an invader in the conflict escalation.
} 
to speculate further on the real probabilities both claims had of been respected by third parties and compare them. To solve their conflict, they need to get rid of the entrepreneurial errors on which they base their claims, by «fine-tuning» their speculations on the uses of economic goods. Only once they have established more accurate and informed complementary expectations they can agree on who has a legitimate claim over the other and decide who is to bear the costs already incurred.

However, any possible solution necessarily entails the existence of two ethical institutions: several property and binding contracts. We have mentioned that the fact of scarcity is the root of all material conflict. If economic goods were abundant, there would be no need for any party to take care of the costs caused by the conflict for there would be none. Paul would find as many identical mules as he wants, so he would not have lost any of the services he does as a consequence of Ulpian's acts. Scarcity is a fact about the world, and it has its set of implications.

[O]nly because scarcity exists is there even a problem of formulating moral laws; insofar as goods are superabundant («free» goods), no conflict over the use of goods is possible, and no action-coordination is needed. Hence, it follows that any ethic, correctly conceived, must be formulated as a theory of property, i.e., a theory of the assignment of rights of exclusive control over scarce means. Because only then does it become possible to avoid otherwise inescapable and unresolvable conflict. (Hoppe 2010, 235)..$^{28}$

Conflict will only be solved once one party is recognized as the legitimate cost-bearer. Which is the same as saying scarcity demands that only one party be entitled to the particular services of economic goods in dispute - that there is one legitimate claim. If we do not recognize anyone entitled to them, then there is no solution to any material conflict for no one can have a claim on nothing and, therefore, no one can be obliged to bear the costs.

${ }^{28}$ Rothbard also defends this position. (See 1997, 274). 
Several property is the ethical institution upon which these entitlements or rights are based. (See Hayek 1991, 12). ${ }^{29}$

What several property entails is that property:

1. Generates a relationship of belonging of a particular economic good to an agent (or several). (See Harper 2003, 74) The relation of ownership places the agent as an owner. The owner is always a person, and there can potentially exist as many owners as people. Ownership entails that the owner is in a position to control the owned thing. (See Hülsmann 2004, 51).

2. It is it originated ex nihilo. This means that its primitive origin lies in goods that were not owned and become owned as a result of some conduct. After they become owned the first time they can later be owned by someone else only derivatively, by coming to own things that were previously owned by someone. The conducts that create ownership come down to the three traditional categories developed by John Locke's homesteading principle: appropriation, production, and exchange. (See 1980, 18-29). ${ }^{30}$

${ }^{29}$ The alternative to several property, unitary property, is incapable of this entitling. By unitary property, we mean a political institution which gathers all the property titles in one person, be it a natural person or an entelechy (like society). If this is the case, then all expectations are equally void as in the event of an absence of property in which no one is entitled to anything, except those of the one owner, which are absolute. In a system of no property or of unitary property all conflicts are doomed to perpetuate in time.

For further inquiry, the philosophical case for property rights have been brilliantly defended by many libertarians: Ayn Rand, (see 1964a, 107-08) and Tara Smith offer an Objectivist justification, (see 1995, 189-93), and Murray Rothbard works in the Aristotelian tradition. (See 1998, 45-50) Hoppe has developed a Kantian/Misesian justification, (see 2006, 339-46) while Mises expounded an utilitarian one, (see 1962, 37-55) Hayek an evolutionary perspective, (see 1978a, 102-09) and Kirzner a justification based on the ethics of entrepreneurship. (See 1989, 98).

${ }^{30}$ Even if one disagrees with the main tenets of the labor theory of property, Locke's typology is consistent with several property. This typology is not original to the philosopher but was inspired by the modes of acquiring property developed in Roman law. (See Nicholas 1976, 117-120, 130-132, 136-138)

It is also important to know that taking Locke's typology does not mean agreeing with the Lockean provisto. Homesteading is, in fact, harder to justify when we consider things not owned to be belonging to all. 
3. Entitles the owner to dispose of his property as he sees fit. The owner has to be in a position to control the asset. He is entitled to make the good an object of his actions without any restriction from third parties - as long as those parties' property is respected as well. ${ }^{31} \mathrm{He}$ can also renounce to property over a good, be it for someone else (making him a derivative owner) or not. (See Harper 2003, 75).

Only if several property is assumed can the conflicting parties reconcile their expectations and assign the costs caused by the conflict. However, for any agreement to be effective it needs to be fulfilled, and if it is not so, it has to be enforced. That is, the agreement needs to oblige. Binding contracts are institutions that establish agreements that have to be fulfilled — pacta sunt servanda-, or otherwise enforced. ${ }^{32}$ Their main function, though not the only one, is to articulate consensual transfers of property. (See Harper 2003, $82)$.

There is an intimate relationship between contracts and property rights because they both establish a protected sphere of action. «Inasmuch as he [man] validly contracts, his claims on others become, as it were, an extended "property right" (just as their claims

Kirzner proposes a revised theory of appropriation which develops over Locke's theory. «In this view, a producer is entitled to what he has produced not because he has contributed anything to its physical fabrication, but because he perceived and grasped the opportunity for its fabrication by utilizing the resources available in the market. This is clearly an example of finding and keeping.» $(1979,196)$.

Moreover, Sugden develops on the spontaneous appearance of certain conventions: those of possessor and first-claimant. (See 2005, 58-107) These «natural» conventions are analogous to the Lockean typology, for they establish rules of first possession and exchange.

${ }^{31}$ In this respect, a person's physical integrity is considered analogous to property. This is deemed self-ownership. (See Rothbard 2004, 92-93).

${ }^{32}$ For further inquiry on the philosophical basis con contracts: Randy Barnett makes a significant development on the many contractual theories and their flaws. (See 1986, 2-12) He moves on to develop a consent theory of contracts which serves as an excellent explanation of why contracts are to be enforced and, especially, why promises, in general, are not to. (See 1986, 12-20) Kinsella develops a different perspective, the title transfer theory of contracts, informed by the principles of the libertarian natural law. (See 2003). 
on him become part of their extended property rights).» (Rizzo 1985, 869).

Any solution to conflict entails the existence of these ethical institutions. ${ }^{33}$ However, several property and binding contracts are insufficient to bring about a solution. These abstract principles say nothing about how we are to solve particular struggles. (See Harper 2003, 62) ${ }^{34}$ Several property just reveals that someone has to be the owner and therefore have a title over the economic asset, and binding contracts just establish that if there is a contract between the owner and someone else, he is obliged to fulfill it. They do not tell what the limits of the entitlements are, by which particular conducts are they acquired or transferred, or how are they to be exercised..$^{35}$

${ }^{33}$ We agree with Barnett: The two fundamental ethical institutions are several property and contracts based on the requirements of decentralized jurisdiction and consensual transfers. (See 2014, 64-66).

34 "Of course, in suggesting that legal rights should correspond with background rights, I claim neither that we can use natural rights to derive legal rights, nor that we can always know what a particular person's background rights are, independent of the processes that produce legal rights. [...] background natural rights are highly abstract, and many very different sets of rules or laws may be consistent with them.» (Barnett 2014, 22).

«[T] he natural rights of several property, freedom of contract, and first possession (and the other rights to be identified later) are extremely abstract. By this I mean that they cannot be applied automatically and logically to any but the simplest of actual disputes. The natural right of several property and the right of first possession, for example, does not specify in sufficient detail all the permissible or impermissible ways that property and be used or acquired. The right of freedom of contract does not tell us how identify those actions which constitute consent to transfer lights. More specific guidance is required.» (Barnett 2014, 84).

${ }^{35}$ Hayek noted the unfitness of several property to solve actual conflicts: «Only where, as in the case of moveable objects (the "chattels" of the law), it was approximately true that the effects of what the owner did with his property in general affected only him and nobody else, could ownership include the right to use or abuse the object in any manner he liked. But only where both the benefit and the harm caused by the particular use were confined to the domain in which the owner was interested did the conception of exclusive control provide a sufficient answer to the problem. The situation is very different as soon as we turn from chattels to real estate, where the "neighbourhood effects" and the like make the problem of drawing appropriate "boundaries" much more difficult.»

«Precisely where those boundaries are most effectively drawn is a very difficult question to which we certainly have not yet found all the final answers. The conception of property certainly did not fall ready made from heaven. Nor have we yet 
There is a significant portion of Austrian theorists who have argued that all solutions to material conflicts can be deduced from the ethical institution of several property. They believe there are ethically determined rules which morally oblige all individuals, and that those rules are attainable by pure reason. Murray $\mathrm{N}$. Rothbard is a major exponent of this point of view. (See Rothbard 1998, 29-160) Walter Block, (see 2004) Guido Hülsmann, (see 2004) Hans-Hermann Hoppe, (see 1988) and Stephan Kinsella, (see 1996) are some of the most prominent exponents of what has come to be known as the libertarian natural law.

However, even though praxeology is allegedly the root of the libertarian natural law theory, (See Kinsella and Tinsley 2014, 97) it is oblivious to the human interactions present in the resolution of conflicts. It establishes certain ethical a priori requirements to human action and, based on them, seeks to solve any possible dispute over economic means. What praxeology ought to do, and what is the purpose of this work, is to acknowledge the forces present in every conflict and its resolution to understand how freely acting individuals in the real world solve conflicts. To elaborate an ideal picture and then pretend to force it upon individuals will seldom lead us to that understanding. That's the reason why the theory here expounded does not focus on the content, but rather, on the process of rules.

succeeded everywhere in so delimiting the individual domain as to constrain the owner in his decisions to take account of all those effects (and only of those effects) we could wish. In our efforts to improve the principles of demarcation we cannot but build on an established system of rules which serves as the basis of the going order maintained by the institution of property.» (1978a, 109).

On the other hand, Epstein observes that binding contracts will also be insufficient to provide all the answers in actual cases: «[T]he merits of freedom of contract in no way depend upon the accidents of time and place. Acceptance of that basic principle will not however put an end to all contractual disputes. It remains to discover the terms of given contracts, usually gathered from language itself, and the circumstances of its formation and performance. Even with these aids, many contractual gaps will remain, and the [private or public] courts will be obliged, especially with partially executed contracts, to fashion the terms which the parties have not fashioned themselves. To fill the gaps, the courts have looked often to the custom or industry practice. The judicial practice makes good sense and for our purposes introduces an element of dynamism into the system.» $(1980,254)$. 
Finally, libertarian natural law theorists overlook the mentioned fact that said ethical institution could hardly give solutions to any possible conflict. As we have established, none of the parties in a dispute get any information on what the legitimacy of their claims was, based on this institution. This issue becomes even more apparent when we face «hard cases» in which we usually find two «innocent» parties. ${ }^{36}$

\section{Human Interactions in Conflict Resolution}

There are three traditional ways in which parties may seek to solve their conflict: negotiation, mediation, and adjudication. The first is the method by which both sides, through direct interaction, aim to reach an agreement on how to take care of the costs. The second method is the one in which both parties, through indirect interaction, seek the same result. That is, they reach for the help of a third party to serve as an assistant of communication, but they do not give said party any power of decision on how the conflict is to be solved. In both cases the interaction is simple: Both sides will continue to participate until they reconcile their expectations and assign the costs accordingly. ${ }^{37}$ If at any point, they feel the process is useless, they will seek for an alternative, be it continuing their conflict or adjudication.

The third method is that of adjudication. It is the process by which the parties reach for a third, impartial party to make a better speculation of what they had to expect, getting rid of their entrepreneurial errors, determining who has a legitimate claim, and allocates the costs accordingly. ${ }^{38}$ In this process, the third party has a

${ }^{36}$ Even Hülsmann, an advocate of the libertarian natural law himself, acknowledges that this radical apriorism in law cannot give solutions to all legal problems. (See 2004, 62-63).

${ }_{37}$ The interactions among parties in negotiations and mediations can be quite complex. There is a vast literature on the subject that indicates it. However, for our praxeological purposes, these do not present such interesting insights.

${ }_{38}$ «The task of the judge will be to tell them what ought to have guided their expectations, not because anyone had told them before that this was the rule, but because this was the established custom which they ought to have known.» (Hayek 1978a, 87). 
power of decision over the conflict, and he will solve it with a ruling. The main advantage of adjudication is that it will always reach for a proposed solution, a rule, which is a standard of conduct allocating costs as a consequence of the particular circumstances of the conflict. ${ }^{39}$ However, the rule is not «the ultimate data of the legal process for the legal philosopher, just as prices are not the ultimate data of the economic process for the economist.» (Leoni 1991, 192) The particular interactions that produce said rules are of the utmost interest to our study.

Some may say that the role of the adjudicator is arbitrary. ${ }^{40}$ Some may suggest that even though he is asked to make a more accurate speculation, he can rule anything he wishes to solve the conflict. However, significant forces are determining the margins upon which he may exercise his discretion. We will now illustrate the complex logic behind the adjudicator's evaluation of the parties' expectations: Let's take again the case in which Ulpian steals Paul's mule for this purpose. Let's imagine the adjudicator decides, either by mistake or discretion, that Ulpian had the legitimate claim. However, it happens that Paul's expectations were correct, and he had the legitimate claim on the mule. In said case, Paul would find many alternatives that are cheaper than the one ruled by the adju-

39 It is a standard of conduct since it establishes what parties are to do in relations to said costs, either restitute them (and how) or internalize them. This type of rule is both substantial and a remedial, primary and secondary. (See Hart 2012, 80-81)

It is also necessarily a causal proposition, which attributes certain consequences to certain circumstances.

At this point, it is important to note that we suggest that rules of law are necessarily a product of conflict. This excludes all behaviors which are always observed and never cause conflict from our concept. We consider this type of behavior to be customs rather than rules (see below). The reason for this is that these behaviors do not present the causal structure that rules do, they do not give a particular consequence -of cost bearing- to a particular conduct - of acting against what is deemed socially sanctioned- because there is no record of people acting that way.

For the same reason, we exclude from our concept of rules of law other social norms like etiquette. Even though there are instances of people acting against what is socially sanctioned in this matter, these standards do not impose any material cost on them (just spiritual or moral).

40 It will be a logical conclusion if we take David Friedman's position that the role of the judge is necessarily one of comparing individual utilities. (See 1989, 179) As we know from the Austrian tradition, this is an impossible task, and it would turn the role of the adjudicator arbitrary. In our elaboration, we prove it is not. 
dicator, for individuals in society in general would value his claim and be willing to uphold it and demand a redress. He would probably refuse to comply; challenging the rule ${ }^{41}$ before another adjudicator on the basis that the original did not properly fulfill the task he was asked to. He could also remain in conflict, for individuals in society will impose most of the costs on Ulpian by way of social punishment, for they will see Ulpian as the wrongdoer. In the end, the adjudication will be unfruitful and the adjudicator a failure. $\mathrm{He}$ needs to make his ruling attractive enough for Paul to prefer it over his alternatives to avoid this.

Now, let's say the adjudicator is capable of accurately speculating what expectations were for Paul, making Ulpian pay for the costs. If the facts are unchanged, it will be hard for Ulpian to find an alternative that will be willing to rule differently, for individuals in society, in general, would not sanction his expectations. Even if he finds it, given that Paul's claim enjoys social favor, he would have no incentive to comply for there would be plenty of alternatives for him. Moreover, if they do not solve the conflict, other individuals will socially punish him, for they see him as the wrongdoer. ${ }^{42}$ The adjudicator also needs to make his ruling attractive enough for Ulpian to prefer it over his alternatives, but in this case, his ruling does work. ${ }^{43}$

${ }^{41}$ Since we are studying the spontaneous production of customary law absent of coercive institutions, we must assume that every party is free to challenge a particular ruling if he finds it unfitting. An adjudication is based on contract, and like any contract, it can be a source of conflict that demands further adjudication. Therefore, it is not a «final decision,» enforceable through the use of force as we find in modern states.

${ }^{42}$ In particular, cases in which an aggressor is unwilling to solve the conflict, it may even be the case that other parties and adjudicators can order the use of force to make him appear before them and comply with the rulings. Still, this is a sensitive measure, for any use of force may be subjected challenge. If said parties or adjudicators do not have the sufficient evidence, or if the injury is not severe enough to justify it, a different adjudicator may punish them for proceeding this way.

The use of force in this particular circumstances do not belittle the spontaneous character of the process so far described, (See Hayek 1978a, 45) for it is subject to scrutiny.

${ }^{43}$ In this context, in which parties do not have an objective reference to which claims society is willing to uphold, we can arrive into a spiral of challenges. For instance, the first adjudication rules for Ulpian, and Paul challenges it before a different adjudicator. The second adjudicator upholds Paul's claims, but then Ulpian 
At this point, it is clear that the adjudicator seeks to make his decision attractive enough for both parties to comply, and can only do so by evaluating their alternatives. ${ }^{44}$ Only an accurate speculation can inform such a rule. ${ }^{45}$ As far as he can do this effectively, his adjudications will be successful, and both parties will be willing to

decides to challenge the decision. A third adjudicator rules for Ulpian, then Paul will challenge the ruling again, and so on. This situation does not pose a problem but in fact, reveals the logic behind the whole process of conflict resolution through rulings. Sooner or later, one of the parties will run out of «friendly adjudicators» willing to rule in their favor. Because expectations are probabilistic speculations of the particular conducts that individuals in society will exercise concerning the services of particular economic goods, the party that runs out of friendly adjudicators will necessarily be the party with the wrong expectations, and therefore, with illegitimate claims. Not enough individuals in society will be willing to uphold his claims. In our case, Paul would prevail.

What about the unlikely case they both have almost equal number of friendly adjudicators? This situation might force parties to seek a middle ground solution if they want to end the conflict effectively.

However, it is unlikely that parties would find themselves in such a situation because it entails high costs. Every adjudication implies fees, and the delay in conflict resolution produces uncertainty costs. It is likely that parties, through entrepreneurship, will try to speculate on what the final situation of such a spiral of challenges will be and therefore be willing to accept a ruling when they deem it to be better than the possible alternatives they might find. Through entrepreneurship, they anticipate possible alternatives and act so as to avoid from going all the way down the line.

It is also likely that adjudicators will try to speculate on what a spiral of challenges will lead to. This is especially relevant in the case in which both parties have a significant number of potential friendly adjudicators. If the first adjudicator anticipates this, he will be able to come out with a middle ground rule himself, preventing the parties of engaging in such a long spiral of challenges. Moreover, it would be a proper and accurate speculation.

${ }^{44}$ This answers some of the concerns raised by Van Den Hauwe on the similarities between the adjudicator and the entrepreneur. (See 1998, 105-06) There is indeed a profit motive in the adjudicator as much as it is in every other entrepreneur. He wishes to be a successful adjudicator to attract new customers. To do so, he must make a reputation of a successful conflict-solver. The most elemental way to achieve this to get the most rulings unchallenged, and the only way to get that is to satisfy both parties. Moreover, parties will be contented as long as they find the decision cheaper than the alternatives.

${ }^{45}$ This was arguably the traditional role of the Roman jurist. His aim was to solve disputes, and to do so he set himself to discover which are the expectations of society. As Leoni puts it: «The Roman jurist was a sort of scientist: the objects of his research were the solutions to cases that citizens submitted to him for study, just as industrialists might today submit to a physicist or to an engineer a technical problem concerning their plants or their production. Hence, private Roman law was something to be de- 


\section{comply. They will find the ruling cheap when compared to its al- ternatives, abide by it, and reconcile their expectations in doing so. ${ }^{46}$ Arbitrary rulings can seldom serve this purpose, for the more legitimate claims are, the costlier this rulings are for one of the}

scribed or to be discovered, not something to be enacted - a world of things that were there, forming part of the common heritage of all Roman citizens.» $(1991,83)$.

Hayek develops on the attitude of the judge in the same line: «The distinctive attitude of the judge thus arises from the circumstance that he is not concerned with what any authority wants done in a particular instance, but with what private persons have "legitimate" reasons to expect, where "legitimate" refers to the kind of expectations on which generally his actions in that society have been based. The aim of the rules must be to facilitate that matching or tallying of the expectations on which the plans of the individuals depend for their success.» (1978a, 97).

We must add to this point what Benson says about acceptance of a ruling, not only by the parties but by the groups around them: «In order to satisfactorily end a dispute, the decision must be acceptable - verifiable - not just to the victim and offender but also to the groups or firms representing these parties and to groups that might be drawn into a confrontation with one of the groups involved in the dispute.» $(2011,365)$

Finally, my description of the role of expectations is similar to that made by Fuller: «Instead, therefore, of speaking vaguely of an obligation arising through mere custom or repetition, it would be better to say that a sense of obligation will arise when a stabilization of interactional expectancies has occurred so that the parties have come to guide their conduct toward one another by these expectancies.» (1981, 219-20).

${ }^{46}$ Several authors have posed the dynamics of customary law as games of coordination. (See Hargreaves-Heap and Varoufakis 2004; McAdams 2000; Rutherford 1996; Sugden 2005) According to Richard McAdams, legal disputes develop like hawk/dove games, in which both parties lose the most by both assuming aggressive (hawk) strategies, each party gets the most by playing hawk if mixed strategies are played, and both sides get less benefit if both play passive (dove) strategies. (See 2000, 1679-80) He bases his analysis on the developments of Robert Sugden, who studies spontaneous orders from a game theory perspective. (See 2005, 58-62).

However, there is a fundamental problem with this approach. It takes rules as a product of mathematical equilibrium in controversies, and to do so abstract the actual situation from its context. It studies conflict resolution as the interaction of two isolated individuals without external influence. The conclusions on the self-enforceability of rules drawn this way hardly reflect the complex interplay of real conflict instances. As we develop throughout this paper, the influence of the adjudicator and institutions like ethics and customs is decisive in the ruling of a case.

Nevertheless, we may draw some insights from this approach: Parties aggressively sticking to their claims (playing hawk) won't reach an agreement and have the most to loose, so in a dynamical development they will tend to move away from this situation. It is the function of the adjudicator to assign these roles (hawk or dove), which are assumed by the parties once they evaluate their alternatives. This will make one party assume a more hawkish role and the other a more dovish, while not necessarily them being totally hawk/dove strategies. 
parties when compared to the alternatives. An understanding of the interactions described here is the contribution that enables us to form the core of a rule theory.

We must add that the mentioned interactions do not fully determine the decision in any particular case. There is arguably a spectrum of possible solutions that would serve the same purpose, for parties would find them cheap when compared to the alternatives. This spectrum can be wide or narrow depending on the context.

\section{Further Precisions on Adjudication}

a) Original Sources Informing Rules

In the scenario already described, in which to be successful the adjudicator is asked to make an accurate estimation of what was to parties had to expect, the question remains on which circumstances is he to base said expectations. What facts can be taken into account to speculate on what the actual probability of third parties of sanctioning a behavior was? Besides the historical considerations surrounding the case, the following sources are likely to accomplish this task:

1. Several property: The main source upon which parties base their expectations are likely to be property titles based on the institution of several property. Considering it is an institutional prerequisite to solve any dispute, it is probable for parties to expect the services of economic goods based on whether they have a property title over them or not. The ethics of several property abstractly informs the content of those entitlements, but as we have mentioned, it is not enough. Some aspects, like the particulars of their acquisition, limits and way of exercise need to be estimated according to social uses and practices. Still, even though abstractly, the fundamental ethics of several property informs expectations to a great extent.

2. Binding contracts: Parties will expect that the other parties fulfill the contracts they have agreed. Like with several property, the institution of binding contracts will inform their execution. 
Still, some of its aspects also need to be established by common uses or practices, like validity and reach. ${ }^{47}$

3. Customs: Customs are the social uses and practices active in a particular social context, and they help fill in the gaps left by the prior sources. Because of their nature, they are reliable in providing information on what behaviors individuals in society will sanction..$^{48}$

The function of the adjudicator regarding customs is twofold, first to properly articulate them and then to derive their implications for what was to be expected by the parties. This is because they usually remain unarticulated in words until the moment when we want to give them legal relevance. As Hayek said:

The process of a gradual articulation in words of what had long been an established practice must have been a slow and complex one. The first fumbling attempts to express in words what most obeyed in practice would usually not succeed in expressing only, or exhausting all of, what the individuals did in fact take into account in the determination of their actions. The unarticulated rules will therefore usually contain both more and less than what the verbal formula succeeds in expressing. (1978a, 77).

${ }^{47}$ Rule adjustment to these principles is not automatic or immediate. The process of rule formation includes instances of «fine-tinning» rules to be more consistent with these principles. Criticism based on the ethical institutions is essential to this stage. «[T] he principle of rational criticism suggests that, while a conventional rule is needed and cannot be logically deduced from the abstract background right of several property, some specific rules can be rationally criticized as inconsistent with this right.» (Barnett 2014, 121).

We must insist that this is not to say that ethical institutions fully determine rules, they just «provide a theoretical frame or boundary. More than one set of legal precepts lies within the frame and natural rights and rule of law principles do not specify a single or unique choice among them. These theoretical considerations do, however, help identify the many sets of rules that are outside the frame and therefore inconsistent with either justice or the rule of law or both. Abstract natural rights and rule of law principles exclude wrong answers rather than definitively establish right ones.» (Barnett 2014, 111).

${ }^{48}$ Not all customs are adequate to inform rulings, but only those related to the application of the principles above mentioned and which produce proper solutions to particular conflicts. 


\section{b) Cost Allocation}

On a different issue, concerning the exercise of allocation costs, we have mentioned they are the foregone satisfactions the invaded party experiences. However, as far as they are forgone, they cannot be restituted. No one can give Paul his foregone satisfactions, but only substitutes. Complaints usually manifest what the invaded party considers being a replacement for his foregone satisfactions; which take the form of new claims over the same or other economic goods. The task of the adjudicator in the allocation of costs is to speculate on what the proper substitutes are. ${ }^{49}$

Again, some could say that such a task is always arbitrary, for the adjudicator could estimate the substitutes - say monetaryas he wishes. However, if we understand the interactions developed in the prior section, we will find this not to be true. Whatever monetary substitute he applies faces competing alternatives

${ }^{49}$ We have already stated that there can be instances of complex conflict. These are cases in which there is not one conflict but a multitude of related conflicts over different services of economic goods to be solved. These are generally present in three situations: when the invaded party claims more than one service of economic goods as a consequence of the invasion; when there is conflict escalation (spiral) before the parties decide to reach for a solution; and when the adjudicator finds it necessary to establish additional compensations than the ones asked by the parties as a redress. We already developed the first two cases in previous notes on this paper. The third one can take place when, for instance, the adjudicator rules that Ulpian is to give back Paul's mule, but that Paul gives a monetary compensation of 100 sestertii to Ulpian for he knew he had a credit over Papinian when he bought the animal. Even though both parties were claiming the services of the mule in their statements, the adjudicator finds it necessary to add compensation. He has added and solved an additional conflict - on the 100 sestertii- that was not originally apparent. This is typically the case of comparative negligence.

Cases of complex conflict are relevant because they aggregate particular conflicts to allocate costs. This means that they are not always winner-takes-it-all cases, but usually, set them in a middle ground. In Paul and Ulpian's last case no one deals with all the expenses of the complex conflict, but only in part. Paul loses 100 sestertii; Ulpian loses the mule. It is because in cases of complex conflicts some party's claims may be upheld for some of the particular conflicts but not for the others.

What we mentioned does not belie the fact that particular conflicts, which are always clashes of claims over the same services of a particular economic good, need necessarily to be solved in a winner-takes-it-all fashion. The reason for this is scarcity; the same services cannot be enjoyed by different individuals simultaneously so both cannot have a legitimate claim over them. 
for both parties. Back in Paul and Ulpian's case, let's say the mule dies after it was seized by the latter. The adjudicator arbitrarily values it in 100 sestertii and rules for Ulpian to restitute the amount. If it turns that the real market substitute would be 50 sestertii, then Ulpian will find many cheaper alternatives to the ruling (many other adjudicators would rule him to pay 50 sestertii) and will not be willing to comply.

\section{c) Scope of Application of Rules}

Additionally, we must add that a ruling applies only to the parties in conflict. (See Benson 2011, 283) In the absence of political power intervening in the legal process, there is no way to force prior rulings to individuals. Because of this, is not in the role of the adjudicator to produce rules that will have a social impact, for he cannot force them on society. Rules, in this context, are backward looking and not forward looking. ${ }^{50}$

To conclude this section, we have to stress on the fact that effective adjudication, as we mentioned, will generate a rule which remains unchallenged. This rule becomes a powerful aid in the coordination of human action and further human conflicts. We will now study what the effects of rules are on a spontaneous order and how they influence and are influenced by human interactions.

${ }^{50}$ By pointing out this, we prevent from falling into Hayek's mistake regarding rules. Considering rules to have a forward looking element puts him in the position of having to assign moral and political ends to the judge, and to avoid this, he held that judges had to solve based only on prior rulings. However, as Hasnas points out, this is only pushing the normative choice one step back. (See 2005, 101-03). 
IV

RULES

\section{Information and Coordination}

Effective rules - those accepted by the parties in conflict, remaining unchallenged- condense valuable information otherwise hard to attain. «[L]aw works by what it says in addition to what it does.» (McAdams 2000, 1651) These rules are true assessments of what is to individuals should expect given certain circumstances in a particular social context. If Ulpian is ordered to give back the mule to Paul, and that ruling remains unchallenged, it generates a focal point upon which other parties can originate expectations. ${ }^{51}$

Let's imagine that, after Paul and Ulpian's ruling, another conflict arises between to different parties: Jones and Smith. Jones had bought a car from Crusoe, and one night, Smith decides to seize it because he had a credit with the latter. If Jones and Smith decide to solve their conflict by adjudication (avoiding the costs of a potential conflict spiral), the adjudicator will find he does not have to inquire into the alternatives to determine which would be the most attractive ruling possible. He is also delivered, for practical purposes, from the necessity to check the first sources that inform rules (principles of several property, binding contracts and customs). All he has to do is verify what happened in a similar prior case (that of Paul and Ulpian). He will find it more profitable to rule in the same line as the previous ruling (making Smith pay for the car), for if the former rule remained unchallenged, his is likely

${ }^{51}$ This effect is what Richard McAdams has called the «expressive powers of law.» He develops his theory based on games of coordination. As we have explained, these games miss some of the characteristics of human action. However, they are insightful from a praxeological point of view nevertheless. McAdam summarizes his argument in this statement: «In each of these situations [of conflict], one player [or both] prefers to coordinate at some equilibrium other than the one the third party selects. That is the conflict that makes the game mixed motive. But the desire to avoid a costly coordination failure is sufficient to make that player play the salient strategy, which is the one named by the third party.» $(2000,1677)$ The third party here is what McAdams calls «the focal point,» which is the role that rules play in my development. By becoming focal points, rules force an «equilibrium» upon parties who would prefer a different result but wish more intensively to coordinate. 


\author{
to do as well. In turn, both Jones and Smith will find that they also \\ need not inquire on alternatives. As long as the adjudicator rules in \\ the same line as the prior rule, they will take it as the cheapest so- \\ lution. $^{52}$
}

\footnotetext{
${ }^{52}$ The process described so far is somewhat similar to that described by Hasnas: «Note the nature of the process. Human beings live together without fixed, known rules of behavior. No central authority exists with the power to establish and enforce such rules. Conflicts inevitably arise, often resulting in violence that disrupts normal life in the community and undermines cooperative activities. This creates strong social incentives to find an alternative method of resolving the conflicts. At first, the members of the community encourage disputants to voluntarily negotiate settlements and facilitate such negotiations by acting as mediators. As this process reduces social strife, publicly mediated negotiations become mandatory, and thus, more frequent. As certain types of negotiated settlements prove successful and are repeated, the members of the community come to expect that similar disputes will be resolved similarly. They begin to base their behavior on these expectations. They also take them into consideration when mediating subsequent disputes, basing their judgment of what constitutes a fair accommodation at least in part on what they believe the parties should have expected given the resolution of past disputes. This makes it more likely that subsequent disputes will be resolved in the same way as previous ones, further reinforcing the emerging expectations.» He then adds: «Note also the basic normative features of this process. In the early stages of development in which disputes are resolved through negotiation, settlements must be regarded as fair by both parties to command mutual assent. The purpose of community involvement is to help discover such "fair" compositions. But as successful compositions are repeated, people come to expect future cases to be resolved in the same way and feel unfairly treated if their expectations are violated. To be accepted as fair, proposed settlements must now conform to the evolving public expectations. This requires that new disputes be resolved in the same way as past similar ones, i.e., that like cases be treated alike. The operation of this principle over time gives rise to identifiable and definite rules of behavior. In this way, an entire body of customary law arises purely from a commitment to fairness that is operationalized in the form of the principle that like cases should be treated alike.» $(2005,87-88)$.

Leoni's interpretation also holds many similarities: «First, judges or lawyers or others in a similar position are to intervene only when they are asked to do so by the people concerned, and their decision is to be reached and become effective, at least in civil matters, only through a continuous collaboration of the parties themselves and within its limits. Second, the decision of judges is to be effective mainly in regard to the parties to the dispute, only occasionally in regard to third persons, and practically never in regard to people who have no connection with the parties concerned. Third, such decisions on the part of judges and lawyers are very rarely to be reached without reference to the decisions of other judges and lawyers in similar cases and are therefore to be in indirect collaboration with all other parties concerned, both past and present.» $(1991,22)$.
} 
But not only the rule will generate a focal point for conflicting parties; it will be a powerful aid to social coordination. Every human interaction can potentially generate conflict, for expectations can always be discoordinated. When an individual is to calculate the costs of an action, he needs not only to value them in economic terms (by calculating his alternatives and monetary costs) but also from a legal point of view (by calculating the likeness of it to produce conflict and the costs he would have to bear if it does). As explained by economic science, the entrepreneur estimates the market prices of tomorrow's products based on yesterday's, so that he can calculate the costs he can incur today. (See Böhm-Bawerk 1930, 223-34) In the same way, he estimates what the probabilities that future parties will sanction or punish (and how) his enjoyment of some services of an economic asset based on what they did yesterday. We call this exercise «legal calculation,» which is a type of economic calculation, and which informs expectations. Similar to market prices, «The task of rules of just conduct can thus only be to tell people which expectations they can count on and which not.» (Hayek 1978a, 102).

To sum it up, rules work in two ways: They inform individual expectations before a conflict even arises ${ }^{53}$ and inform the adjudicator's solution once it appears. They do so by instructing parties on what adjudicators will rule in the present by looking to what they ruled in the past, and telling the adjudicator what the parties should have expected today based on that parties had expected yesterday. This way parties accommodate their conduct and come to expect that individuals in society sanction certain behaviors, and adjudicators inform their decisions by acknowledging what parties should have expected from economic goods. Rules tell men what to expect, and they bring about the consequences of not behaving accordingly. This is what we mean when we say rules are self-enforcing. ${ }^{54}$

\footnotetext{
${ }_{53}$ «How can we ignore the fact that many norms which are usually considered as legal (and specifically those which are regarded as basic for any legal ordering), lack any coercion, as well as the mention of coercion in the formula in which they are expressed.» (Leoni 1991, 193).

${ }^{54}$ The treatment made on the development of the institution of rules holds many similarities to Menger's theory of the spontaneous generation of money. (See 2011, 257-
} 
We must add that rules in as much as institutions, aid man in coping with uncertainty. ${ }^{55}$ They develop spontaneously on top of each other, condensing information. As Hayek manifested: «Rules are a device for coping with our constitutional ignorance. There would be no need for rules among omniscient people who were in agreement on the relative importance of all the different ends.»(1978b, 8).

There are four additional effects the emergence of rules has on society besides those already described:

1. Rules define property rights and contracts: They give objectivity to the very abstract principles of both ethical institutions we already noted, - several property and binding contracts. (See Barnett 2014, 101) Rules establish how individuals are to acquire property in different cases; limit how it has to be exercised and transferred; what differentiates a contract from a mere promise; ${ }^{56}$ how we are to enforce them; which clauses are valid or invalid and to what extent they oblige, just to name a few examples of the infinite areas in which both institutions need definition. This definition is in no way deter-

61). However, most importantly, the self-sustaining phenomenon is parallel to Mises' regressive theory on the value of money. (See 1998, 405-13).

We do not use self-enforcing in the sense proposed by game theorists - which we mentioned in a prior note- (See Van Den Hauwe 1998, 108) They are not the product of mathematical equilibria but human action and interactions in an institutional context.

${ }_{55}$ As Lachmann puts it: «[S]ince human action is more volatile than the conditions of nature, it is far less easy to predict. In a complex society such as our own, in which the success of our plans indirectly depends [sic] on the actions of millions of other people, how can our orientation scheme provide us with firm guidance? The answer has to be sought in the existence, nature, and functions of institutions.» $(1971,49)$.

${ }^{56}$ On this topic, Barnett's criticism of the «reliance theories» of contracts, (see 1986, 4-5) and the relationship they might have with the expectations are particularly interesting. We do subscribe to his opinion that we cannot justify the enforceability of contracts on expectations that courts will uphold them without risking circular reasoning. This is the reason why we subscribe, in general terms, to his consent theory. However, it is also true that expectations based on previous rules influence what we consider a valid contract and many of its other aspects. 
mined but depends on the institutional evolution of law in a free forum. ${ }^{57}$

2. Rules narrow the spectrum of possible solutions in particular cases: By generating a precise and objective focal point upon which to base expectations, they bridge the range of outcomes that would be accepted by both parties. Adjudicators have a more restricted freedom to assign costs than what they had based on the abstract original sources of expectations. However, as we will see, even though they are usually compelled to follow prior rules, they still have some freedom to part and modify them when they find it beneficial for the solution of a particular conflict.

3. There is a progression in the process of rule formation: «Easy cases» usually generate the first rules, in which expectations without prior rules are more easily attainable by the adjudicator. Once human interaction produces further rules, we find two major phenomena: the rules will cause the avoidance of conflict in easy cases or the exploration of alternative methods - like mediation or negotiation. This is so because explicit prior rules make apparent to the parties what the solution will be if they seek adjudication, which makes its costs hard to justify.

The second phenomenon is that more complex cases, which were initially tough to solve, get logical and consistent solutions built over the rulings on easy cases. Complex rules need prior matters to be established in other rules so they can build on top of them. Only by identifying the rules that solve simple cases can we solve progressively harder ones.

4. The emergence of rules is the basis for the studies of legal academics and scholars: Once human interaction generates rules of law, legal scholars can undertake the task of analyzing them, compiling them and giving them the proper coherence. These studies are somewhat influential on the interpretation and application

${ }^{57}$ The different forms private property can take is apparent in Boudreaux and Drago's study on African tribes. The case of the tribes in the Nigerian plateau is particularly interesting. They developed private property with many differentiating aspects from one tribe to the other. As the authors point, property rights get defined in greater detail as the demand for land increases, population rises, and transaction costs get higher; (see 2007, 73-78), but the actual form they take depends on the community's adaptation. 
of rules. In a sense, legal scholars collaborate with adjudicators in the creation and definition of rules. As Hasnas puts it:

Academics or other legal scholars could, of course, analyze the reported cases in order to abstract rules of law, much as the legal scientists of the late nineteenth and early twentieth century did. They could publish the results of their analyses in casebooks to help students learn the law, in articles and treatises to help attorneys prepare cases more efficiently, and in more popular works to help the members of public understand both what to expect if they become involved in litigation and how to conform their behavior to the law. Further, these rules could play a role in litigation in that the rules of evidence would permit a litigant to introduce them to show that he or she acted reasonably in light of past legal decisions. $(2005,107) .^{58}$

\section{Abstraction and Reformulation}

\section{a) Abstraction}

As mentioned, rulings only affect the involved parties. However, said rules, as far as they influence further expectations on third parties, are usually adopted to solve other conflicts. To be able to do this successfully, rules must be deprived of the peculiarities of the original case, keeping only those factors that are relevant. In other words, rules need to be abstracted. As Hayek said, proper

\footnotetext{
${ }^{58}$ Or as Barnett says: «the comparative advantage of academics who are legally inclined is the concentrated attention they can afford a body of doctrine to map its precise contours and its internal inconsistencies. Academics who are economically inclined can assess the likely consequences of a legal precept. Academics who are philosophically inclined can assess the information gleaned by these other academics to see how a legal precept and its consequences squares with abstract principles of justice. Philosophers and economists write in journals that are read by legal scholars who in turn combine their insights with those of legal theory in articles published in law journals (edited by students still under the influence of their teachers) and treatises that are read by judges (or their postgraduate clerks). Increasingly, economists and philosophers are writing in law journals as well. Moreover, academics exert considerable influence on judges through judicial law clerks who have only just emerged from their professors' tutelage.» $(2014,127)$.
} 
rules are «directed to unknown people and [...] abstracted from all particular circumstances of time and place and refers only to such conditions as may occur anywhere and at any time.» $(1960,150)$

It is our impression that there are three tasks adjudicators and legal scholars must practice to properly abstract a rule:

1. Generating types of conducts: This process abstracts a real life situation from all of its irrelevant factors. By doing so a type (or class) of case is created, that is a general, abstract formulation which can encompass many actual situations. (See Whitman 2009, 24-25) For instance, let's say that to seize the mule, Ulpian approaches Paul's house armed with a gun by night, takes the animal and flees. Out of this real world case, a rule may apprehend the following typical case: Seizing someone else's property without consent, and call it «stealing.» However, there are many degrees of abstraction when we generate types of conducts. For instance, in the case mentioned above, the type may be stealing a mule, stealing a mule at night, or stealing a mule armed with a firearm, or just stealing at night or stealing with a firearm. ${ }^{59}$

2. Labeling parties: Abstract rules also label parties involved in the type conflict (i.e. creditor and debtor in a case of due credit). ${ }^{60}$ Labeling roles and not people is the adequate task for abstraction in law. If people were labeled, as in a rule that states «Anytime someone sues Paul, he gets 100 sestertii in awards,» they would be forced to internalize the costs it generates. That is, anybody dealing with Paul will make sure that there are com-

${ }^{59}$ Douglas Glenn Whitman develops a theory of abstraction applied to rules of law in the Hayekian tradition. The main argument is that «Rules with intermediate abstraction provide [a] benefit. Adopting rules that abstract from specifics and focus on a few relevant factors allows us to make predictions for entire groups and classes. For those classes, we can make reasonably confident predictions about "correct" behavior. But if the rules become too abstract, the classes become larger, and we become less confident about our ability to determine "correctness" for any given member of a class.» $(2009,28)$ He suggests that this approach solves the false dichotomy between rules and standards, by providing rules that are neither case by case nor too abstract. (See 2009, 30-32).

${ }^{60}$ Game theorists consider labeling as a way of generating equilibriums by focal points. (See McAdams 2000, 1693-94). 
pensation methods to any dispute that will take care of the loss of 100 sestertii in case he needs to sue Paul; otherwise, he will refuse to deal. This rule is ineffective to solve real conflicts and will eventually be in the best interest of Paul, as of anybody else, that adjudicators drop it. Very strict roles, subsuming only a few agents, have similar effects to labeling people. ${ }^{61}$

This point is related to that of permanently biased adjudication. Cases in which, even though the rule labels a role and not a person, a particular adjudicator resolves the conflict based on the persons intervening. Let's say a particular adjudicator always solves Paul's disputes by awarding him. Once other parties acknowledge this fact, they will force Paul to internalize the costs of the rulings or refuse to deal. In the end, it will be in Paul's best interest not to solve his conflicts with this adjudicator but with some other who solves based on abstract rules that label roles.

3. Establishing awards: When the invader party is ruled to restitute the invaded, we usually say the rule awards the latter. Rules that award invaded parties need to manifest such awards, not in concrete terms - be it monetary amounts or particular economic goods- but in abstract ones. For instance, proper rules should never state that the creditor is to pay « 100 sestertii» to the debtor, but rather that he is to pay «the total amounts of capital plus interests.» Alternatively, that the robber is to give «a mule» to the robbed, but that he is to "return the stolen object.» This makes the same rule applicable to a vast amount of cases, regardless of the costs involved in them. A rule that always awards the same amount, regardless of costs (similar to a fine), is useless to solve conflicts.

${ }^{61}$ The function of roles is related to the purpose independence of the rule. Rules with proper role labels are unable to serve particular purposes. Purpose dependence makes rules unstable in two respects: once their ends are met they lose utility; and because of their narrowness, they do not allow for new cases to add information about them. (See Whitman 2009, 36-37). 
b) Reformulation

On a different topic, we have explained that rules are spontaneous institutions that build over prior rules and inform expectations that are the base of future rulings. However, we have also mentioned that rules apply only to the parties concerned and cannot be forced upon others. This gives each adjudicator in each new conflict a certain degree of freedom to adjust and reformulate said rules. If he finds that some rule does not make an accurate speculation any longer, he can modify it to compensate for inaccuracies. There are three cases we can think of in which such an adjustment becomes necessary: cases in which conflicting rules exists, cases in which conflicting interpretation of the same rules exists, or cases in which the expectations have drastically changed due to external shocks. ${ }^{62}$

About conflicting rules, Hayek pointed:

While the judge's starting point will be the expectations based on already established rules, he will often have to decide which of conflicting expectations held in equally good faith and equally sanctioned by recognized rules is to be regarded as legitimate. (1978a, 115).

Moreover, about conflicting views on the same rule he said:

Such a person called in to adjudicate will often find it necessary to articulate and thereby make more precise those rules about which there exist differences of opinion, and sometimes even to supply new rules where no generally recognized rules exist. (1978a, 99).

However, the most interesting case is undoubtedly the last one. Even though rules are typically the main sources that inform expectations, this is not always the case. Changes in the geographical, economic or political environment, individual preferences or

${ }^{62}$ We are not considering at this point changes due to principled criticism based on the ethical institutions we have developed. As we explained in a note earlier, we consider this not a reformulation but a substantial part of the process of rule formation. 
customs may modify social sanction regardless of a previous rule, making it obsolete. The former rule itself may not be able to produce and accurate speculation, given these new circumstances. In this case, the adjudicator is to incorporate this shift. Even though the law is a self-sustained phenomenon in which past rules influence new rules, it is not an impervious one, that is, it is susceptible to some degree of change and adaptation to external shocks that affect individual's expectations.

Since new situations in which the established rules are not adequate will constantly arise, the task of preventing conflict and enhancing the compatibility of actions by appropriately delimiting the range of permitted actions is of necessity a never-ending one, requiring not only the application of already established rules but also the formulation of new rules necessary for the preservation of the order of actions. (Hayek 1978a, 119).

The role played by lawyers in changing rules is of the utmost importance. Adjudicators may be resilient to change, in which case is in the role of the lawyer to point out the relevant circumstances that will make a compelling argument for changing a particular rule. Lawyers perform acts of entrepreneurship in this case: They have to be alert to the evolution in the context of the conflict and try to arrive at arguments that will convince adjudicators of modification. (See Schwartzstein 1994, 1069-72).

We must add that every process of rule modification necessarily faces, to some degree, the same interactions of first rulings. Parties, aware of a change in the rule, may become more alert on their alternatives to the adjudication. Only modifications that are attractive enough for both sides to comply will survive this process without being challenged. We may say the same about a lack of rule amendment in a changed environment.

\section{The Market of Conflict Resolution: Forums and Forum Rules}

Adjudication is a service, and like any service in a free market, it faces competition. Adjudicators capable of developing rules which accurately estimate what parties are to expect and offer cheap 
solutions to disputes will prevail over less successful ones. ${ }^{63}$ In turn, adjudicators, in general, will internalize the benefits of successful rules which, once generated, become general conditions of welfare. (See Rothbard 2004, 4) In this environment of competition, only successful rules will survive. We like to call the rules that survive the competitive process at a particular time and in a given context forum rules. ${ }^{64}$

Given that, in different social settings, people will tend to value certain circumstances rather than others, and therefore generate different expectations, it is unlikely that one forum ruleset will become universal for all particular matters. Societies of various professions, in different markets or within different territories will uphold different claims. ${ }^{65}$ Social interaction may produce different forums (markets) of various sizes and natures.

A private system of law would generate efficiently sized «market areas» for the different aspects of law, and perhaps many would be smaller than most nations while others would overlap many of today's political jurisdictions. (Benson 2011, 300). ${ }^{66}$

${ }^{63}$ We need to note that even though this is the chief respect on which adjudicators compete, it is not the only one. Their costs, the way of collecting evidence, their procedures, and many other factors determine the success of particular adjudicators in a free market.

${ }^{64}$ The forum was traditionally the Roman place where people attended to solve their disputes with the help of figures like the Praetor and the Jurist. It seemed proper to call the rules that prevail in a free market interaction by the name of forum rules, the same we call the prevailing prices in market interaction market prices.

${ }^{65}$ Carl Menger already noted this: «Certain conditions resulting from general human nature and thus appearing everywhere produce similar institutions of law everywhere by their nature, while tribal differences and variety of external conditions and mental spheres result in differences in law. What is considered law and justice in one nation may in part not appear so to another. With the change of conditions, the same phenomenon may appear in the same nation in different eras of its development. Everywhere law is set in the current of time and of human conditions and only in respect to these does it have its special existence.» (2009, 228-29).

${ }^{66}$ Lisa Bernstein's study is of the utmost interest. Bernstein studies how the market of diamonds deals with rules that are not geographically based and don't have any relation to any state legislation. It is a historical account of how, even in legal systems as intervened as today's, particular settings may produce forum rules. (See 1992)

Another interesting study is that of Ellickson. He shows how in Shasta County, California, most conflicts among landowners are solved based on rules that differ from the legislation. (See 1991, 15-82). 
However, there is no reason to believe said forums would be impervious. Various forums may adopt successful rules generated in a different one.

Aspects of a particular group's law that prove to be efficient can be revealed to another group in the process, and they can also adopt it. This kind of process characterized the standardization of the Law Merchant throughout Western Europe. Efficient rules adopted by one merchant community tended to spread to other communities quite rapidly. (Benson 2011, 366).

By this process, some forums will tend to merge while others to divide. Some forums will keep some rules for longer periods, while some may find them obsolete after a short time. People will also switch from one forum to a set of rules they find inconvenient to another (provided, of course, that the people they want to deal with are also willing to switch forums). The result of this very complex interactions will produce levels of uniformity and permanence in rules that are a result of individual preferences and expectations.

We have now fully described the spontaneous process of generation of rules and the many benefits this institution brings to human coordination. In the next section, we will focus on how legislation can trump this process, and the consequences this can produce.

\section{$\mathrm{V}$ \\ LEGISLATION}

The legislation consists of a set of commands generated by the political authority, and whose enforcement is always imposed by the use (or threat) of violence over particular societies within a territory. ${ }^{67}$ It is a deliberate product of particular human minds. ${ }^{68}$

${ }^{67}$ In this respect, legislation is always in violation of the political non-aggression principle developed by Ayn Rand and later adopted by Murray Rothbard. (See Rand 1964b, 125-27; Rothbard 1998, 51-52).

${ }^{68}$ They are a particular instance of what Hayek would call thesis. (See Hayek 1978a, 127). 
The crucial question in the case which concerns us is what are the shortcomings of legislation vis a vis customary law? Can both coexist? Rules condense a particular kind of information that the legislation lacks. Social order and cooperation depend on the use of dispersed knowledge of this type, which is unavailable to any single human mind. (See Hayek 1945, 519) Rules have a function similar to market prices, which are the essential economic institution that allows men to make use of such vast amounts of knowledge without the need to apprehend it. ${ }^{69}$ The legislation, on the other hand, can seldom bring such benefits to human coordination, for it is the product of a particular mind and not of human interaction. It cannot condense the vast amounts of information from such interactions, for that information can never be available to a single mind. The legislation, in this respect, is similar to official prices, and equally inimical to human cooperation. (See von Mises 2011, 7-12).

However, the complications of legislation is aggravated by the fact that, once enacted and potentially enforced, it generates a focal point which is necessarily different from the one generated by rules. This forced focal point produces new expectations on individuals. Nevertheless, those new expectations are all in discoordination with the values and preferences of individuals in society. Individuals may value, for instance, the property over roads highly, and would be willing to uphold any property title over said economic goods. However, in the presence of legislation that forbids said property, particular individuals will expect that no one

Hayek restricts this definition only to that legislation which has organizational purposes like public law, administrative law, constitutional law and even criminal law. (See Hayek 1978a, 131-38) As we will see, there are strong arguments to believe all legislation is, in fact, thesis.

Leoni would also argue that legislation has the same characteristics as law generated by monopolistic judges (Common Law). (See 1991, 24-25) Hasnas reinforces the argument by making the case that current Common Law, based on judge-made precedent, is not in fact anything like «customary law» or nomos. (See 2005, 89-98).

${ }_{69}$ This approach provides a normative justification of freely generated spontaneous rules from an Austrian perspective that is fundamentally different from the one developed by traditional law economists, based on Paretian and Coasean efficiency considerations. (See Ellickson 1991, 167-84) We expand on the difference between this approach and mainstream law and economics in the epilog. 
owns roads, regardless of social values. The role of the adjudicator in said scenario will be that of speculating based on commands and not on said values. The interactions we find in a free forum of adjudications is absent from this process. This new focal point forces excessive costs over one party in benefit of the other, or sometimes just in benefit of the authority. In a case in which the political authority seizes a road which was built by a particular individual, the latter is forced to bear the costs that in a free forum he would not have been obliged to bear. This makes consistent coexistence between law and legislation impossible.

However, these are not all the consequences. Once political power introduces legislation, individuals by way of entrepreneurship will adapt existing rules to the new context. After a period they will find a way to regain the benefits, even though in a less efficient fashion, of solving conflicts according to individual preferences in society. The political authority, which enacted the legislation in the hopes to get a particular outcome, will find that people in society are reluctant to produce it. In this situation, political power will tend to enact further legislation to attain said ends, just like it enacts further official prices and regulations for the same reasons. (See von Mises 2011,9) Progressively all rules will tend to be repealed by legislation, and we will necessarily reach a state of legal socialism. If coexistence of both is attempted, legislation will tend to cannibalize customary law.

The legislation is also incapable of generating legal certainty, which is an institutional requirement for the law to serve its purpose. In the case of rules, permanency, as has already been exposed, is to be determined by individual preferences in a free society. Legislation can never attain this level of effectiveness is establishing legal certainty:

We are actually far from attaining through legislation the ideal certainty of the law, in the practical sense that this idea should have for anybody who must plan for the future and who has to know, therefore, what the legal consequences of his decisions will be. While legislation is almost always certain, that is, precise and recognizable, as long as it is «in force,» people can never be confident that the legislation in force today will be in force tomorrow or 
even tomorrow morning. The legal system centered on legislation, while involving the possibility that other people (the legislators) may interfere with our actions every day, also implies the possibility that they may change their way of interfering every day. As a result, people are prevented not only from freely deciding what to do but from foreseeing the legal effects of their daily behavior. (Leoni 1991, 9-10).

The problem with the change in legislation is not the change in itself, for change is always necessary to some extent. We have already explained how rules cope with external shocks that modify expectations, producing the precise levels of change. The problem is the unexpected change. The abrupt change in legislation made in the pursuit of particular ends has a hard time coping with the institutional framework of existing rules and expectations. (See Lachmann 1971, 80) On the other hand, change in rules usually takes time, and this serves a fundamental purpose. «It takes time even for the participants to find out which action was successful and which was not. It takes further time for such knowledge to become diffused among potential imitators.» (Lachmann 1971, 89)

The mentioned consequences are irritated by the fact that legislation does not have to compete..$^{70}$ The political authority has a monopoly on the production of legislation, a monopoly which is inconsistent with the free forum process of rules. By way of competition, we are assured that the rules that survive are always those that better reflect expectations in society, and correct the many mistakes adjudicators can make in particular instances of conflict resolution along the way. This process is absent in legislation.

We must add that Hayek argues that at some point, legislation can efficiently incorporate customary rules. (See 1978a, 87-89) This seems to assume that rules can reach a stationary point of equilibrium, in which the form they take (be it legislation, common law

${ }^{70}$ Some may argue that some alternative dispute resolution methods like international arbitration pose some competition to legislation. The truth of the matter is that this competition is usually very marginal because of the high, sometimes prohibitive, costs of these methods, which are not a consequence of the market but of the legislation itself limiting the scope of its effectiveness. 
precedent or forum rules) is irrelevant for the content is already given. However, praxeology contradicts the argument of static efficiency and favors a concept of dynamic efficiency in which change is the relevant and perennial factor. (See Huerta de Soto 2014, 10; Leoni 2013, 157-58) In law, as well as in economics, there is no stage of final rest, but only constant change. The legislation is never able to cope with this dynamism.

The legislation is, therefore, artificial, as it condenses none of the information which is necessary for rules to play their fundamental role in human coordination. The legal socialism to which legislation inevitably dooms us has similar effects to those of its economic counterpart. It produces massive discoordination among market agents, making solutions to conflicts way more expensive for one or both parties than they would otherwise be. This frustrates many mutually beneficial business as well as easy solutions to practical disagreements. It also deteriorates over time, for new legislation will necessarily be increasingly arbitrary if no prior rules are condensing the necessary information on individuals' expectations. At one point, legislation may destroy all the information entailed in rules, fully replacing it with artificial commands and depriving individuals of its use. ${ }^{71}$ The effects of this legal chaos

${ }^{71}$ Jesús Huerta de Soto has undertaken one of the main historical investigations that seem to demonstrate this phenomenon. In his book Money, Bank Credit and Economic Cycles, when explaining the theoretical development of the irregular-deposit contract throughout time, he notes that, in Roman law, it was considered as a duty to the depositor always to keep the amount deposited or tantundem. However, in the middle ages several commands (somewhat similar to legislation) by the three main monotheistic religions imposed the prohibition on believers to lend money and charge interests (usury). This artificial commands had a negative influence over the original rules concerning irregular-deposit, which gave rise to the depositum confessatum, a distorted use of the contract used to disguise regular loans. This, in turn, produced a change in the theoretical basis of the irregular-deposit which, with the purpose of detecting the real intentions of the parties, became assimilated to regular loans. This theoretical distortion then brought further complications when it generated expectations among parties and served as an argument for the legitimacy of fractional reserve banking. (See 2006, 20-36, 64-69) This development illustrates how original rules, developed to solve particular conflicts among individuals, were deeply distorted by commands, which produced a systematical legal discoordination among parties. It also made transactions costlier and conflicts harder to solve, and incentivized further distortion by the construction of new artificial rules built over them to solve the original problems (i.e. legal tender laws), producing even further discoordination. 
are apparent today, in a world very advanced on the path to legal socialism, in which rules are progressively less apt to solve conflicts, costlier to the parties and serve as a tool of disrupting rather than achieving coordination. In the words of Leoni:

[A] legal system centered on legislation resembles in its turn [...] a centralized economy in which all the relevant decisions are made by a handful of directors, whose knowledge of the whole situation is fatally limited and whose respect, if any, for the people's wishes is subject to that limitation. $(1991,22)$.

This way we conclude our explanation of the terrible consequences of interfering with the spontaneous order of rules, and provide a normative justification of customary law. It is now apparent that legislation has dire implications for human coordination, only par to official prices.

VI

CONCLUDING REMARKS

To understand the misfortunes caused by socialism, we first needed a proper understanding of the dynamics of the free market. In the same way, to understand the disastrous effects of legislation, we first need to comprehend the vast dynamics of spontaneous customary law emergence. To do so, as Leoni pointed out, we find the precise tool of inquiry in the method of economic science. Throughout this paper, this proves to be the adequate tool of analysis and has enabled to reach our purported goal: We have a fundamental criticism of legislation based on its lack of information necessary to social coordination.

Additionally, the praxeological rule theory we have expounded lies in the heart of the legal phenomenon. It explains the nature, inception and effects of a legal order based on the action of free agents. Just like prices, rules are one of the core aids of social coordination which permit the great societies to develop. This knowledge permits us to make additional inquiries in the realm of legal science: It serves as a theoretical framework from which to study many historical instances of law and interpret them appropriately. 
This scientific understanding is also of immense value to grasp the benefits of free legal forums when compared to state generated legislation.

However, just as economic theory is not exhausted with price theory, but finds in it one of its starting points, a praxeological legal theory cannot be satisfied with a rule theory. Further exploration is necessary until we can finally attain all the implications of a praxeological general theory of law. In the end, we are confident the fruits of applying praxeology to the law will prove as rich and vast as they have proven to be in economic science.

\section{EPILOG \\ ADDITIONAL IMPLICATIONS OF A PRAXEOLOGICAL RULE THEORY}

The following is a succinct review of some of the additional consequences of the theory expounded in this paper:

\section{To Legal Theory}

Legal theory is mainly concerned with the question of what law is. The theory developed in this article may help us answer this and some other issues of importance. First and foremost, law is a science. From our perspective, we may argue that is a branch of what Mises called praxeology, the science of human action. (See 1998, 11-29) It is so because the principles of human action are at its core. Its sister science is economics or catallactics, which Mises defined as a science "mainly concerned with the analysis of the determination of money prices of goods and services exchanged on the market.» $(1998,235)$ Law, which to follow the Misesian tradition we also like to call psifismics, ${ }^{72}$ on the other hand, is the science concerned mainly with the settlement of conflicts through rules.

${ }^{72}$ We use this term in a similar way as Mises used catallactics to name economics alternatively. It comes from the Greek term psifisma, $\psi \eta \dot{\varphi} \varphi \iota \mu \alpha$, which means «resolution.» 
The law, understood as the object of the science mentioned above, can be said to be the forum rulesets. More elaborately, the law is the set of rules of conduct which are prevalent in the different social contexts, aimed at solving conflicts by assigning costs among the various parties. Law, as an institution, is directed to the achievement of peace. «The idea of Law is realized at first in the sphere in which the maintenance of peace is most urgently needed to assure economic continuity - that is, in the relation between individuals.» (von Mises 1998, 46). ${ }^{73}$

We must add that law is not developed in a vacuum, it necessitates and implies some institutional premises. Chiefly, as we have seen, it needs several property and binding contracts. In a socialist society, in which force prohibits several property and binding contracts, there is no solution to any conflict, and no rule is possible. ${ }^{74}$ In said society, only legislation can exist. ${ }^{75}$ Both institutions are logically previous to the formulation of law. ${ }^{76}$ Many free market institutions, like money, prices, and competition, (see Menger 2009, 147) also entail similar institutional backgrounds. ${ }^{77}$ In all those

${ }^{73}$ Roscoe Pound makes the same point. (See 1959, 371).

${ }^{74}$ This is a feature law shares with market prices. As Mises argued, socialism is futile because, given the lack of property rights on the means of production, there is not a market to define prices, and economic calculation is impossible. (See 1962, 111-27).

${ }^{75}$ It is of interests that John Austin's famous and influential theory of law takes this socialist model as the reference. He argues that law be a command of the sovereign (the one who people usually obey, and who usually obeys no one) backed by a threat of punishment. (See 1988, 13-14) H.L.A. Hart has expounded the many problems of regarding commands as proper law. (See 2012, 50-79).

${ }^{76}$ This fact contradicts the widely regarded position that several property and binding contracts are a product of law. It is the other way around.

Many laissez-faire theorists also held this vision. Mises, for instance, when referring to legal property expounds law as defining property rights. (See 1962, 37-38) Rothbard argues that the purpose of natural law be to define natural rights. (See 1998, 21-24) Moreover, Benson states that: «Clearly, some system of defining and then protecting and enforcing property rights (property law) and rules of exchange (contract law) is needed for a market system to develop.» $(1989,644)$.

A different position was held by Rapaczynski, who accurately points out that: "The core of the institution of ownership is a matter of unquestioned and largely unconscious social and economic practices that must be rooted in non-legal developments.» $(1996,88)$.

${ }_{77}$ We could say that institutions have a hierarchical structure. We need to presuppose some institutions in the development of further ones. 
cases, prior institutions are a necessary, though not always sufficient, antecedent. (See Harper 2003, 80-81). ${ }^{78}$

\section{To Legal Philosophy}

The question on the philosophical nature of law has occupied legal scholars throughout the centuries. The discussion has ben centered on two debates. First, on whether the law is a product of practical reason or a human posit. (See Murphy 2007, 14-48) Natural law theorists, inspired by Thomas Aquinas, hold that ethical considerations

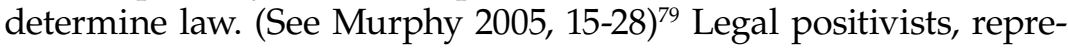
sented by Hans Kelsen in Continental Europe, (see 2009) and H.L.A. Hart in the Anglo-Saxon tradition, (see 2012, 100-09) hold that law is the product of society, which either emanates from authority or any other socially recognized source.

A praxeological approach to law arguably solves this problem. It proves that this is a false dichotomy, for the law is both: It is primitively based on ethics, specifically on the ethics of several property and binding contracts, which inform primitive expectations. However, it is also not rationally determined by them, but a product of human action and interaction. First rules prove to be the bridge between the ethical and the practical. «Unfair rules» — rules which are oblivious to ethical principles - while theoretically possible will tend to be dismissed as defective by the competitive process for they fail to produce accurate speculations by ignoring the very ground of expectations. ${ }^{80}$

Douglass North already pointed out that there are three classes of institutions: constitutional, operating and normative, and that the first ones determine the general character of political order. (See 1981) Even if we do not take this description literally, it is quite clear that institutions need to show some hierarchy.

${ }^{78}$ We take Kirzner's position on the necessity of private property for markets to exists. «[Market] forces can only be relied upon provided a widely shared ethic already exists which firmly recognizes the "rightness" of the property rights system and the corresponding "wrongness" of theft and fraud.» $(2000,85)$.

${ }^{79}$ Murphy builds over the argument for the relation of law and practical reason first exposed by Thomas Aquinas in his Summa Theologiae, found in the Prima Secundae (I-II) questions 90-95. (See 2002, 10-58).

${ }^{80}$ These are instances of what Murphy calls «defective law.» (See 2005, 26-27). 
The second debate in legal philosophy is on whether the law is rationally determined or not. That is, if the law provides an objective and unique answer to every single situation or not. This debate is better characterized in the Hart/Dworkin debate on the "open texture» of law. (See Dworkin 2013, 124-54; Hart 2012, 29-64) Praxeology also proves this to be a false dichotomy: Law is not rationally determined as far as existing rules cannot, at any point, foresee all possible cases of human conflict. However, within that realm of indeterminacy, it is not true and has been argued extensively throughout this paper, that judges are free to create new law. Social values and expectations, whose origins we can trace to the ethics of several property and contracts, restrain them. These ethics play a role similar to that played by principles in the Dworkinian literature.

\section{To the Evolutionary Theory of Institutions}

Our understanding enables us to point out the apparent deficiencies in the Hayekian legal theory. In his evolutionary description of the emergence of customary law, particularly in Law, Legislation, and Liberty, Hayek seems to make no use of methodological individualism. (See Van Den Hauwe 1998, 93) In this work, he stresses that the actions that produce social institutions are somewhere «between instinct and reason.» (See 1991, 11)

However, this seems to overlook some of the characteristics of all human action that we have already defined. It apparently ignores the fact that it is necessarily volitional and rational. (SeeVan Den Hauwe 1998, 92) This seems to bring Hayek to conclude, at times, that the main conduct by which society adopts rules is erratic - and not goal-oriented- imitation, which, when it takes place on the proper rules, achieves group survival, (see 1978a, 19) and not, as this paper suggests, entrepreneurship. Overlooking entrepreneurship brings the author to some dubious conclusions. He says:

The cultural heritage into which man is born consists of a complex of practices or rules of conduct which have prevailed because they 
made a group of men successful but which were not adopted because it was known that they would bring about desired effects. (1978a, 17).

Rule adoption, since an action, necessarily seeks to attain particular effects. This is different from saying that men design the rule for a particular purpose. The kind of erratic imitation the author suggests as the fundamental part of the process, necessarily contradicts the tenets of human action. This conveys the impression to force Hayek to a further mistake: Because man is aimless while adopting rules, it cannot be the case that this adoption is based on their success.

These rules of conduct have thus not developed as the recognized conditions for the achievement of a known purpose, but have evolved because the groups who practised them were more successful and displaced others. (1978a, 18).

Rules, its suggested by Hayek's passage, are adopted aimlessly, and those groups who were lucky enough to adopt the right ones survived, while the others perished. ${ }^{81}$ Once again, randomness would contradict the basic tenets of human action.

We must add that elsewhere, Hayek would regard the process of spontaneous order in markets (which he develops based on methodological individualism) and the evolutionary process of institutions as one and the same. $(1952,41)$ However, given his apparent reliance on blind imitation and obliviousness to the central role of entrepreneurship in the latter, it has been argued by some scholars that they are not. (See Barry 1982, 11) They hold that very different forces govern both processes, and from a Hayekian point of view, they might be right.

${ }^{81}$ This presupposes that rules, just because they have persisted through an evolutionary process, are appropriate and beneficial, but mere survival can hardly be a test of moral worth. (See Ogus 1989, 404).

"the fact that a pattern of a certain complexity is an unintended consequence of individual actions need not entail that such a pattern has a social "functionality" or that it promotes "the common welfare" or 'the general good'.» (Van Den Hauwe 1998, 86). 
In conclusion, what Hayek seems to miss because of the direction he took is, actually, the source of the strongest argument against legislation and political interference in law: the argument of ignorance. (See Smith 2014, 241) ${ }^{82}$ Adopting erratic imitation as a tool of rule adoption, is incapable of explaining what type of information rules condense and legislation does not, for random behavior is not the product of reason and therefore does not convey any information. Hayek's development on the topic seems incapable of providing an integral normative justification of spontaneous rules. (SeeVan Den Hauwe 1998, 115) One of the motivations for this paper was, precisely, to solve this problem by duly incorporating entrepreneurship into the evolutionary theory of institutions.

\section{To the Theory of Dynamic Efficiency}

In The Theory of Dynamic Efficiency, Professor Jesús Huerta de Soto proposes a new concept of efficiency to rival the «static» or Paretian concept which has prevailed in mainstream economic science for the past decades. (See 2014, 1) Huerta de Soto's argument, summed up, is that Paretian efficiency, which is of technical nature, can never incorporate the entrepreneurial dimension of economics, which is by far the most relevant.

One of Huerta de Soto's proposals for the application of his theory of dynamic efficiency is in the field of economic analysis of law, a discipline which Paretian and Coasian views dominate. (See 2014, 28-29) He points the flawed nature of Coase's theorem, which lies at the heart of all recent developments in the field. (See Coase 1960; Cooter and Ulen 2011, 80-86; Posner 2014, 30-31) The main tenet of the theorem is that, absent «transaction costs,» initial resource allocation is irrelevant, for all goods will necessarily end up being used efficiently (in a static sense). (See Cooter and Ulen 2011, 84;

82 «[T]he insight that a spontaneous order utilizes much more knowledge than can possibly be made accessible to any central agent or agency, is an important conclusion. It gives us reasons for doubting the ability of governments to achieve complex feats of social organization by deliberate planning. It also indicates the essential source of the potential efficiency of market arrangements in comparison to centralized, deliberately-planned arrangements.» (Van Den Hauwe 1998, 102). 
Posner 2014, 50-55) However, Professor Israel Kirzner already exposed the deep mistake in Coase's argument, which is oblivious to entrepreneurship. To be true, the Theorem would demand that all information is given and known, but this is necessarily false. Only through entrepreneurship can man generate and communicate the information on the many maladjustments present in the economy and use the resources efficiently. However, this process is not one of mechanical allocation of resources; it is rather a process of discovery and coordination which aims not at «utility maximization» but wealth creation. (See Huerta de Soto 2014, 15-16).

The praxeological rule theory expounded on this paper is a contribution to the application of dynamic efficiency to the economic analysis of law, and an alternative to the Coasian view. It does so by incorporating entrepreneurship and getting rid of all static considerations of resource allocation. The original maladjustment caused by conflict offers an opportunity to the adjudicator to discover solutions which are cheap for both parties and consistent with social preferences. By doing so, the adjudicator «creates» new information which will aid individuals in future conflicts by providing a focal point of resolution. By this process, all persons learn to govern their behavior according to solid expectations - expectations shared by most individuals in a social context-, which never reach a state of equillibrium..$^{83}$

«From a dynamic standpoint, and individual, a company, an institution or an entire economic system will be more efficient the more it fuels entrepreneurial creativity and coordination.» (Huerta de Soto 2014, 10) We can say the same about the law: The less intervention on entrepreneurship, by way of legislation, the higher dynamic efficiency any legal order can achieve. Allocative efficiency, we may add, is necessarily incorporated in the dynamic perspective, for entrepreneurship is also able to achieve the highest degree

83 Our theory also supports another of Huerta de Soto's views, that «Kirznerian» entrepreneurship can be applied to the spontaneous emergence of institutions like law and money. Contradicting Kirzner himself, Huerta de Soto holds that the process of formation of institutions necessitates entrepreneurial action. (See «La aplicación...») This paper shows the particular mechanisms by which entrepreneurship drives the process. 
of coordination and adjustments necessary for the most profitable use of resources. (See 2014, 11).

Finally, and in the same line as Professor Huerta de Soto, we recognize that we cannot attain dynamic efficiency regardless of ethical considerations. Only the ethics of several property and binding contracts are consistent with it, for only if individuals are capable of enjoying the fruits of their intellect and entrepreneurship, will they be able to exercise them. This is in opposition with the "second fundamental theorem of welfare economics," which states that efficiency is compatible with many initial resource allocations, and therefore, achievable regardless of ethical considerations. It holds that both ethics and efficiency can combine in different proportions. (See Huerta de Soto 2014, 6) However, from a dynamic point of view, ethical resource allocation through private property is a necessary condition for dynamic efficiency to exist. (See 2014, 21).

\section{BIBLIOGRAPHICAL REFERENCES}

Aquinas, T. (2002): On Law, Morality, and Politics. Indianapolis: Hackett Publishing.

Austin, J. (1988): The Province of Jurisprudence Determined. London: John Murray.

Barnett, R. E. (1986): «A Consent Theory of Contract.» Columbia Law Review 86 (2): 269-321.

- (2014): The Structure of Liberty. Oxford: Oxford University Press. BARRY, N. (1982): «The Tradition of Spontaneous Order.» Literature of Liberty 5 (2):

BENSON, B. L. (1989): «The Spontaneous Evolution of Commercial Law.» Southern Economic Journal 55 (3):

- (2011): The Enterprise of Law. Oakland: Independent Institute.

BERNSTEIN, L. (1992): «Opting Out of the Legal System: Extralegal

Contractual Relations in the Diamond Industry.» The Journal of Legal Studies 21 (1): 157-15.

Block, W. (2004): «Austrian Law and Economics: The Contributions of Adolf Reinach and Murray Rothbard on Law, Economics, and Praxeology.» The Quarterly Journal of Austrian Economics 7 (4 (Winter 2004): 69-85. 
BöHm-BAWerk, E. V. (1930): The Positive Theory of Capital. New York: G.E. Stechert \& Co.

Boudreaux, K., and Dragos, P. (2007): «The Evolutionary Path Paths to Property Approaches to Institutional Change in International Development.» London:

COASE, R. (1960): «The Problem of Social Cost.» The Journal of Law $\mathcal{E}$ Economics 3

Cooter, R., and Ulen, T. (2011): Law \& Economics. Boston: Pearson. DwORKIN, R. (2013): «The Model of Rules I Taking Right Seriously.» London: Bloomsbury.

ElliCKSON, R. C. (1991): Order Without Law: How Neighbours Settle Disputes. Cambridge: Harvard University Press.

EpsteIn, R. (1980): «The Static Concept of Common Law.» Journal of Legal Studies 9

FriedMAN, D. (1989): The Machinery of Freedom: Guide to Radical Capitalism. La Salle: Open Court.

FulLeR, L. L. (1981): «Human Interaction and the Law.» In Principles of Social Order Selected Essays of Lon L. Fuller, Durham: Duke University Press.

Hargreaves-Heap, S., and Varoufakis, Y. (2004): Game Theory: A Critical Introduction. London: Routledge.

Harper, D. A. (2003): «Institutions I: Rules of Law, Property and Contract Foundations of Entrepreneurship and Economic Development.» London:

Hart, H. L. A. (2012): The Concept of Law. Oxford: Oxford University Press.

Hasnas, J. (2005): «Hayek, the Common Law, and Fluid Drive.» NYU Journal of Law and Liberty 1 (0):

HAYEK, F. A. (1945): «The Use of Knowledge in Society.» The American Economic Review XXXV (4):

- (1952): The Counter-Revolution of Science: Studies on the Abuse of Reason. Glencoe: Free Press.

- (1960): The Constitution of Liberty. Chicago: The University of Chicago Press.

- (1978a): Law, Legislation and Liberty Vol. 1: Rules of Order. Chicago: University of Chicago Press.

- (1978b): Law, Legislation and Liberty Vol. 2: The Mirage of Social Justice. Chicago: University of Chicago Press. 
- (1991): The Fatal Conceit: The Errors of Socialism. Chicago: University of Chicago Press.

HobBes, T. (1994): Leviathan: With Selected Variants From the Latin Edition of 1668. Indianapolis: Hackett Publishing.

Hoppe, H.-H. (1988): «The Justice of Economic Efficiency.» Austrian Economics Newsletter 9 (2):

- (2006): The Economics and Ethics of Private Property: Studies in Political Economy and Philosophy. Auburn: Ludwig von Mises Institute.

- (2010): A Theory of Socialism and Capitalism. Auburn: Ludwig von Mises Institute.

HuERTA DE SOTO, J. «La aplicación de la teoría kirzneriana de la empresarialidad al surgimiento de las instituciones y comportamientos morales.»

- (2006): Money, Bank Credit and Economic Cycles. Auburn: Ludwig von Mises Institute.

- (2014): The Theory of Dynamic Efficiency. London: Routledge.

HülsmanN, J. G. (2004): «The a Priori Foundations of Property Economics.» The Quarterly Journal of Austrian Economics 7 (4 (Winter 2004): 41-68.

IgLESIAS, J. (2010): Derecho Romano. Madrid: Sello Editorial.

Kelsen, H. (2009): Pure Theory of Law. New Jersey: The Lawbook Exchange.

KinselLa, N. S. (1996): «Punishment and Proportionality: The Estoppel Approach.» Journal of Libertarian Studies 12 (1):

- (2003): «A Libertarian Theory of Contract.» Journal of Libertarian Studies 17 (2): 11-37.

— and Tinsley, P. (2014): «Causation and Aggression.» The Quarterly Journal of Austrian Economics 7 (4 (Winter 2014):

KIRZner, I. M. (1979): Perception, Opportunity and Profit. Chicago: University of Chicago Press.

- (1989): Discovery, Capitalism and Distributive Justice. Oxford: Basil Blackwell.

- (2000): The Driving Force of the Market. London: Routledge.

LACHMANN, L. L. (1971): «On Institutions the Legacy of Max Weber.» Berkeley:

LeEsOn, P. T. (2014): Anarchy Unbound. Cambridge: Cambridge University Press. 
LeONI, B. (1991): Freedom and the Law. Indianapolis: Liberty Fund. - (2013): Lecciones De Filosofía Del Derecho. Madrid: Unión Editorial.

LOCKE, J. (1980): Second Treatise of Government. Indianapolis: Hacket Publishing.

McAdams, R. H. (2000): «A Focal Point Theory of Expressive Law.» Virginia Law Review 8680.

Menger, C. (2009): Investigations Into the Method of the Social Sciences. Auburn: Ludwig von Mises Institute.

- (2011): Principles of Economics. Auburn: Ludwig von Mises Institute.

Murphy, M. C. (2005): «Natural Law Theory.» In The Blackwell Guide to the Philosophy of Law and Legal Theory, edited by Martin P Edmundson, Golding, and A William, Malden: Blackwell Publishing.

- (2007): Philosophy of Law. Malden: Wiley.

Nicholas, B. (1976): Introduction to Roman Law. Oxford: Oxford University Press.

NortH, D. C. (1981): Structure and Change in Economic History. New York: W.W. Norton.

Ogus, A. I. (1989): «Law and Spontaneous Order: Hayek's Contribution to Legal Theory.» Jorunal of Law and Society 16 (4 (Winter):

Posner, R. (2014): Economic Analysis of Law. New York: Wolters Kluwer Law \& Business.

Pound, R. (1959): Jurisprudence. New York:

RAND, A. (1964a): «Man's Rights.» In The Virtue of Selfishness: A New Concept of Egoism, New York: Signet.

- (1964b): «The Nature of Government.» In The Virtue of Selfishness: A New Concept of Egoism, New York: Signet.

RAPACZYNSKI, A. (1996): «The Roles of the State and the Market in Establishing Property Rights.» Journal of Economic Perspective $10(2)$ :

Rizzo, M. J. (1985): «Rules Versus Cost-Benefit Analysis in the Common Law.» Cato Journal 4 (3):

Rothbard, Murray N. (1997): «Justice and Property Rights the Logic of Action I: Method, Money and the Austrian School.» London: Edward Elgar. 
- (1998): The Ethics of Liberty. New York: New York University Press.

- (2004): Man, Economy and State With Power and Market. Auburn: Ludwig von Mises Institute.

Rutherford, M. (1996): Institutions in Economics. Cambridge: Cambridge University Press.

Schwartzstein, L. A. (1994): «An Austrian Economic View of the Legal Process.» Ohio State Law Journal 55

SмIтH, C. (2014): «Hayek and Spontaneous Order Elgar Companion to Hayekian Economics.» edited by Roger W Garrison, and Norman Barry, Cheltenham: Edward Elgar.

SмIтH, T. (1995): Moral Rights and Political Freedom. Lanham: Rowan \& Littlefiend Publishers.

Sugden, R. (2005): The Economics of Rights, Cooperation and Welfare. London: Palgrave Macmillan.

Van Den Hauwe, L. (1998): «Evolution and the Production of Rules, Some Preliminary Remarks.» European Journal of Law and Economics 5 (1): 81-117.

VAN Dun, F. (2003): «Natural Law: A Logical Analysis.» Etica \& Politica 52.

Mises, L. v. (1962): Socialism: An Economic and Socialogical Analysis. New Haven: Yale University Press.

Mises, L. v. (1998): Human Action: A Treatise on Economics. Auburn: Ludwig von Mises Institute.

Mises, L. v. (2011): Critique of Interventionism. Auburn: Ludwig von Mises Institute.

Whitman, D. G. (2009): «The Rules of Abstraction.» Review of Austrian Economics 22 (1): 